\title{
The 11 August 2006 squall-line system as observed from MIT Doppler radar during the AMMA SOP
}

\author{
Michel Chong ${ }^{\mathrm{a}, \mathrm{b} *}$ \\ ${ }^{a}$ Université de Toulouse (UPS), Laboratoire d'Aérologie, Toulouse, France \\ ${ }^{\mathrm{b}}$ CNRS, Laboratoire d'Aérologie, Toulouse, France
}

\begin{abstract}
On the evening of 9 August 2006, a mesoscale convective system (MCS) having a north-south oriented squall-line organization formed over the border between Chad and Nigeria. It propagated westward, intensified over Nigeria on 10 August, and reached Niamey (Niger) at 0320 UTC on 11 August. Its passage over Niamey was accompanied by dust lifting and was well tracked by the Massachusetts Institute of Technology (MIT) Doppler radar. The three-dimensional structure of the airflow and precipitation pattern is investigated from regular radar volume scans performed every ten minutes between 0200 and 0321 UTC. The 3D wind components are deduced from the multiple-Doppler synthesis and continuity adjustment technique (MUSCAT) applied to a set of three volume scans obtained over a time period of one hour, which are equivalent to a three-radar observation of the squall line when considering a reference frame moving with the system and the hypothesis of a stationary field.

Results of the wind synthesis reveal several features commonly observed in tropical squall lines, such as the deep convective cells in front of the system, fed by the monsoon air and extending up to $15 \mathrm{~km}$ altitude, and the well-marked stratiform rain region at the rear, associated with mesoscale vertical motions. Forward and trailing anvils are clearly identified as resulting from the outflow of air reaching the tropopause and transported to this level by the sloping convective updraughts occurring in a sheared environment. In the northern part, a deeper and stronger front-to-rear flow at mid-levels is found to contribute to the rearward deflection of the leading line and to promote a broader (over $300 \mathrm{~km}$ ) stratiform cloud region. Eddy vertical transports of the cross-line momentum mainly accounts for the mid-level flow acceleration due to a momentum redistribution from low to higher levels. The height distribution of hydrometeors and their associated production terms derived from a one-dimensional microphysical retrieval model indicate the distinct roles of the convective and stratiform regions in the formation of graupel and rain, and the respective contributions of cold (riming) and warm (coalescence, melting) processes. Cooling from melting, and heating/cooling from condensation/evaporation processes yield a net decrease and increase of the potential temperature at low and mid-to-upper levels, respectively, with respect to an environmental thermodynamic profile taken three hours ahead of the analysis. Finally, the upper-level rearward flow could convey the non-negligible proportion of ice particles farther from the leading deep convection to the trailing stratiform region, thereby favouring the extent of this region.
\end{abstract}

KEY WORDS convective and stratiform precipitation; updraught; downdraught; microphysics

\section{Introduction}

The documentation of the mesoscale convective systems (MCSs) that are associated with the West African monsoon (WAM) was one of the major components of the special observing period (SOP) of the African Monsoon Multidisciplinary Analysis (AMMA) project (Redelsperger et al., 2006). AMMA was dedicated to improve our knowledge and understanding of the WAM and its variability at particularly daily-to-interannual time-scales and from sub-mesoscale to global scale including mesoscale and regional scale. These MCSs are closely related to synoptic-scale African easterly waves (AEW) and/or the low-level monsoon trough also called the intertropical convergence zone (e.g. Payne

\footnotetext{
${ }^{*}$ Correspondence to: M. Chong, Laboratoire d' Aérologie, 14 Avenue Edouard Belin, 31400 Toulouse, France.

E-mail: michel.chong@ aero.obs-mip.fr
}

and McGarry, 1977; Houze and Betts, 1981). The MCSs account for most of the rainfall over West Africa while the AEWs contribute to modulate them (Reed et al., 1977; Mathon et al., 2002a, 2002b). These AEWs are also found to initiate most Atlantic tropical cyclones downstream (e.g. Avila and Pasch, 1995; Landsea et al., 1998; Hopsch et al., 2007; Chen et al., 2008). Analysing vorticity tracking statistics at 600 and $850 \mathrm{hPa}$ over a 20-year period, Thorncroft and Hodges (2001) showed that the cyclone activity may be influenced by the number of AEWs of significant low-level vorticity amplitude that leave the West African coast.

MCSs in the Tropics and mid-latitudes have been described extensively in previous studies and Houze (2004) provided a complete review of their various internal structures and dynamics along with interaction with larger-scale motions, although they all have regions of both convective and stratiform precipitation. The internal 
structure ranges from quasi-two-dimensional (2D) squall lines to fully three-dimensional (3D) mesoscale systems (Houze et al., 1990). MCSs organized into squall-line systems are frequently observed, consisting of a large cloud system with a well-defined convective line ahead of an extensive trailing anvil cloud (stratiform rain) and preceded by a forward anvil at upper levels. Using conventional meteorological observations, Hamilton et al. (1945) first described tropical squall lines as disturbance lines. Fast motion, long-lasting structure and a well-marked gust-front signature at ground level are common characteristics often reported in numerous past studies of squall-line systems (Betts et al., 1976; Houze, 1977; Zipser, 1977; Leary and Houze, 1979; Fortune, 1980; Gamache and Houze, 1982; Houze and Rappaport, 1984; Chong et al., 1987; Roux and Ju, 1990; among others). The overall airflow within the squall lines presents a 3D structure. At the leading edge, convective-scale updraughts are fed by converging warm, moist boundarylayer air which is subsequently transferred rearward into the trailing anvil. Convective-scale downdraughts fed by mid-tropospheric air participate in the formation of a cold rear-to-front flow normal to the squall line (Zipser, 1969). This flow strongly opposes the front-to-rear flow associated with warm air. A mesoscale updraught within the trailing anvil cloud of the stratiform region and a mesoscale downdraught below it are found to be fed by mid-tropospheric convergence (Gamache and Houze, 1982). This mesoscale downdraught air is composed of drier (low equivalent potential temperature) ambient air that is incorporated into the system from the rear (rear inflow or rear-to-front flow) below the trailing anvil cloud and toward the leading convective region (Chong et al., 1987; Smull and Houze, 1987). Thermodynamic and dynamic processes are invoked to explain the development and evolution of the rear inflow. This descending flow is attributed to the cooling associated with sublimation, melting and evaporation of precipitation particles (Smull and Houze, 1987; Lafore and Moncrieff, 1989) while it could be reinforced in the presence of a mid-level mesoscale vortex generated at the ends of the convective line (Skamarock et al., 1994). Recently Schumacher and Houze (2006) showed that a non-sheared or weakly sheared upper-level environment favours the formation and extent of the stratiform precipitation region, in addition to the ability of the environment to support continual convection, the so-called convective sustainability (Houze, 2004). Futyan and Del Genio (2007) also pointed out the greater convective sustainability over ocean than over land regions to explain the different life cycles of convective systems over the tropical Atlantic and Africa.

The present paper investigates an MCS that passed over Niamey (Niger) early in the morning of 11 August 2006. Data collected by the Massachusetts (USA) Institute of Technology (MIT) C-band Doppler radar are used to characterize the 3D structure of the airflow and precipitation. Unique to this study are the location of the MCS and the application of a pseudo dual-Doppler analysis of singleradar data (Bluestein and Hazen, 1989) in non-optimal conditions. The MCS presents a squall-line organization of the convection and an extensive trailing stratiform cloud, and occurs in an extreme continental environment. The wind analysis is performed as the system enters the radar range so that the storm's motion is mostly along the line of sight of the radar instead of being normal to assure optimal pseudo between-beam angles. The main objectives of this study are to describe the kinematic structure and to investigate the vertical transport of horizontal momentum by the squall line and the main warm (coalescence, melting) and cold (riming) microphysical processes involved in the formation of the precipitation using a one-dimensional (1D) thermodynamic and microphysical retrieval model. The physical conditions necessary for the observed extensive stratiform region will be examined through the related in-cloud flow acceleration and hydrometeor distribution at mid-to-upper levels. Section 2 gives an overview of the synoptic meteorological conditions and the convective systems that prevailed over West Africa on 10 and 11 August 2006. Methods of wind field synthesis from single-Doppler data and thermodynamic and microphysical retrieval are described in section 3, following those described in Chong et al. (2000) and Braun and Houze (1995a), respectively. An advective procedure is used to transform two or more single-radar volume data into pseudo dual or multiple radar data necessary for the determination of the three Cartesian wind components, while the area-mean vertical velocity is used to estimate the vertical profiles of potential temperature and liquid and solid hydrometeor mixing ratios. The deduced airflow and precipitation structure are discussed in section 4 , along with the momentum transports. Section 5 presents the results obtained from the microphysical retrieval model in the distinct convective and stratiform regions. In a companion paper (Risi et al., 2009) the wind field analysed here is used to constrain a 2D transport model including simplified microphysical parametrizations, in order to evaluate the relative contribution of dynamics and microphysics to the evolution of the isotopic composition of the rain over the Sahelian region.

\section{Synoptic context and radar observations}

At about 1800 UTC on 9 August 2006 an MCS formed over the border between Chad and Nigeria, and intensified as it moved westward over Nigeria on 10 August. This system preceded another MCS that formed earlier over Sudan to the east of Chad. Figure 1 shows a series of Meteosat- 8 satellite infrared images (orange colour is the $208 \mathrm{~K}$ level) between 1800 UTC 10 August and 0900 UTC 11 August every three hours. During this period the two major mesoscale convective systems were separated by about $10^{\circ}$ in longitude and both progressed westward while they gradually dissipated on the morning of 11 August. The westernmost MCS which is discussed in this paper was located towards the western edge of Nigeria and extended northward over southern Niger between 1800 and 2100 UTC. It presented a more pronounced linear organization (squall line) than the easternmost MCS near the border between Chad and 
(a)

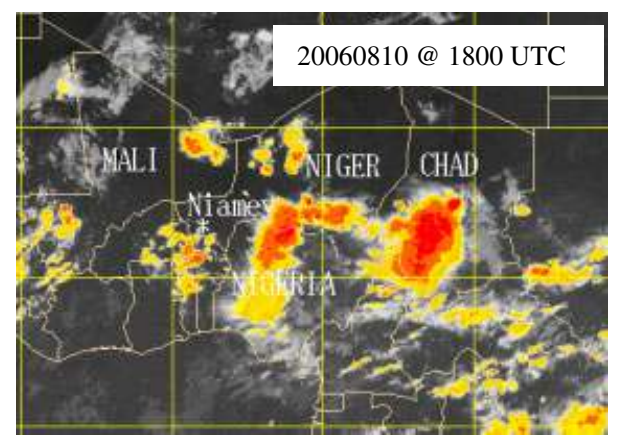

(c)

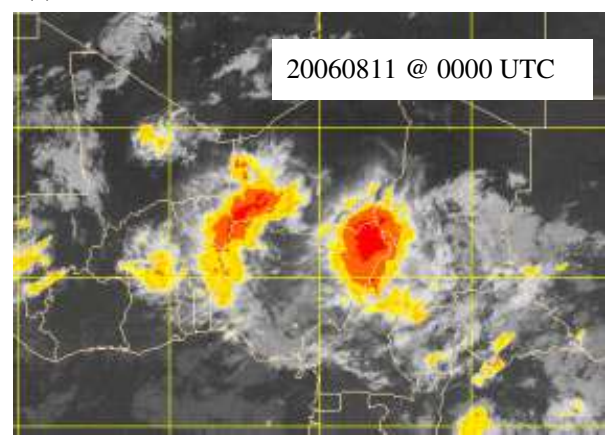

(e)

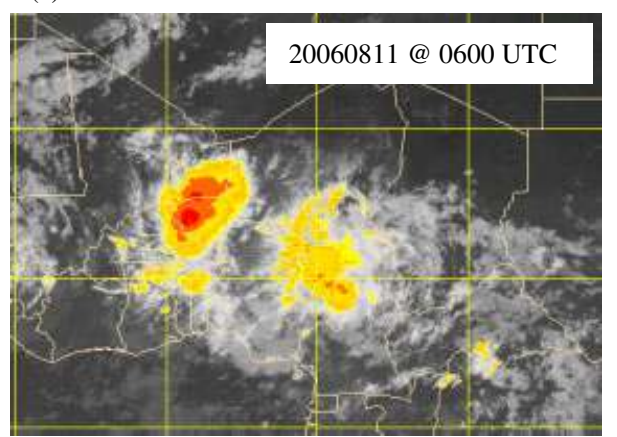

(b)

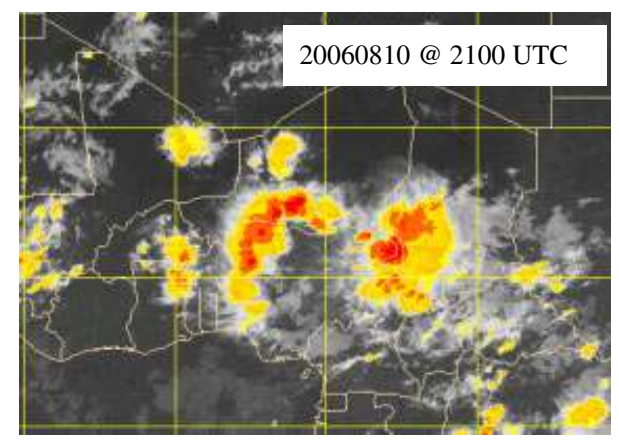

(d)

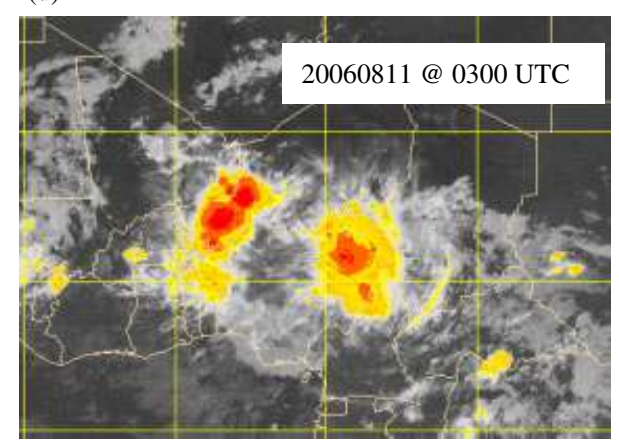

(f)

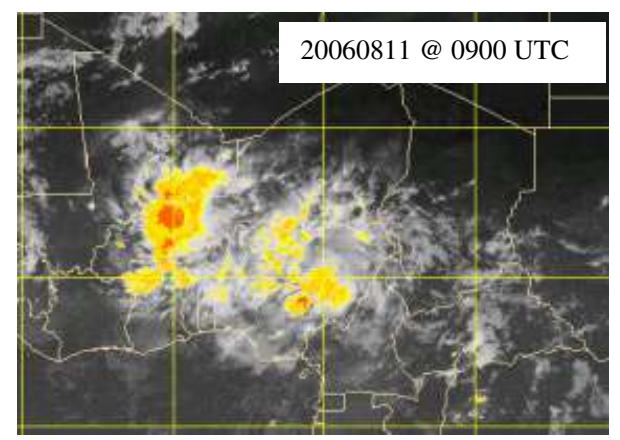

Figure 1. Meteosat-8 satellite infrared images at (a) 1800, (b) 2100 UTC 10 August 2006, (c) 0000, (d) 0300, (e) 0600 and (f) 0900 UTC 11 August 2006, showing the westward propagation of two major MCSs from Chad to Mali. This figure is available in colour online at www.interscience.wiley.com/journal/qj

Nigeria. Moreover, Figure 1 suggests that this squall line was in an early-to-mature stage as it progressed toward and reached Niamey at around 0300 UTC (Figure 1(a)(e)), and it was then in a dissipating phase beyond 0600 UTC as it began to enter eastern Mali (Figure 1(f)).

The prevailing meteorological conditions over West Africa at 1800 UTC 10 August 2006 and 0600 UTC 11 August are summarized in Figure 2 which displays the West African Synthetic Analyses (WASA) issued by the African Centre of Meteorological Applications for Development (ACMAD). These charts were designed to provide a synthetic view of the main key features associated with the West African monsoon (called WASF in the case of forecasted features) in the context of the forecasting activity during the SOP (Lafore et al., 2008). The intertropical discontinuity (ITD) defined as the near-surface position of the interface between the cool moist southwesterly monsoon flow and the warm dry northeasterly harmattan flow was positioned around $20^{\circ} \mathrm{N}$, with a poleward segment over northwestern Mali and southern Algeria, and sloping down to northeastern Niger and Chad in its equatorward portion (Figure 2(a)). During the night, it experienced an overall northward shift (Figure 2(b)) as a manifestation of the monsoon diurnal cycle marked by the intensification of the nocturnal monsoon low-level jet (Sultan et al., 2007; Lothon et al., 2008). At mid-levels (600 hPa) the African easterly jet (AEJ, associated with winds exceeding $10-13 \mathrm{~m} \mathrm{~s}^{-1}$ ) was observed over northern Nigeria around $11.5^{\circ} \mathrm{N}$ before it turned northwestward along the border between Burkina Faso and Niger, and toward Mali. The AEJ did not change position during the $12 \mathrm{~h}$ time interval, and the two observed MCSs were closely connected to it, although many other organized or isolated convective cells were also observed south of the ITD. Trough axes associated with African easterly waves (AEW) and corresponding to the maximum curvature of the winds at 600 or $700 \mathrm{hPa}$ were detected over Ghana and south Mauritania on 10 

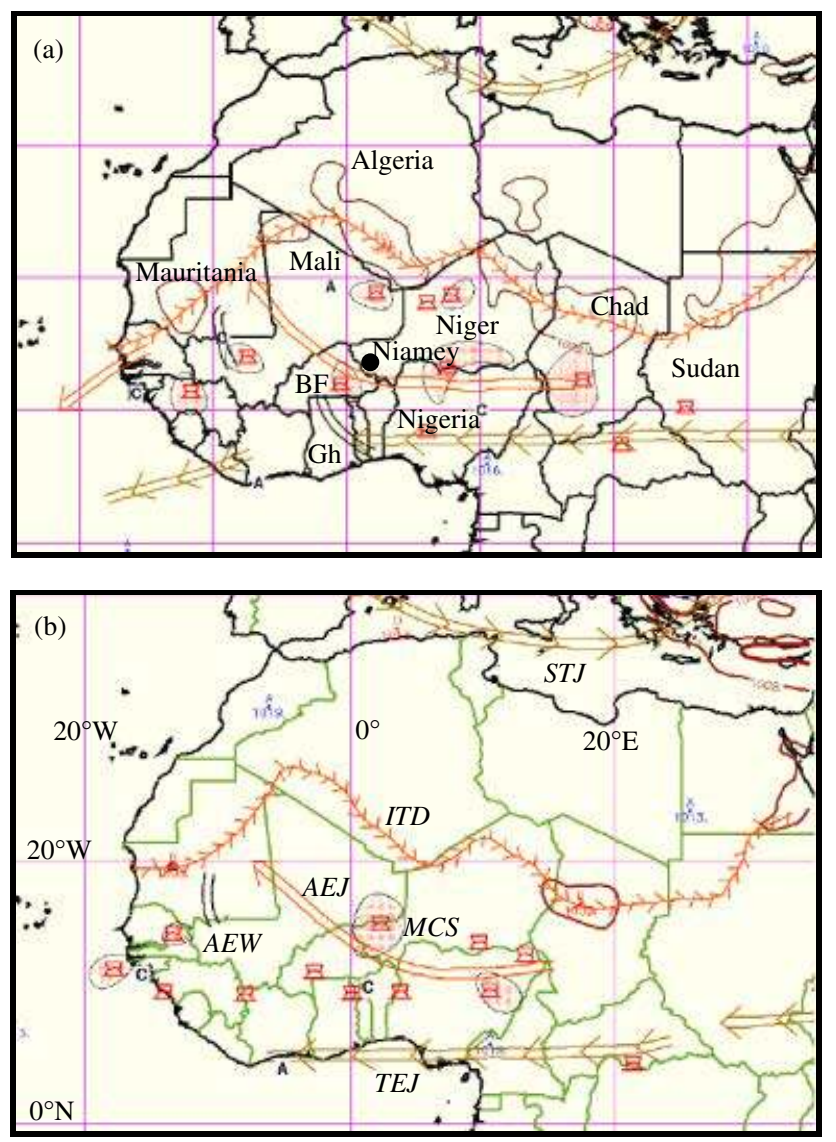

Figure 2. West African Synthetic Analysis (WASA) of the main weather characteristics tracked by the African Centre of Meteorological Applications for Development (ACMAD) at (a) 1800 UTC 10 August 2006, and (b) 0600 UTC 11 August 2006. In (a) some country names are indicated explicitly except Burkina Faso (BF) and Ghana (Gh). In (b) positions of observed mesoscale convective systems (MCSs), intertropical discontinuity (ITD), African easterly jet (AEJ) and wave trough (AEW), tropical easterly jet (TEJ) and sub-tropical jet (STJ) are reported. This figure is available in colour online at www.interscience.wiley.com/journal/qj

August 2006 (Figure 2(a)) and only over Mauritania on 11 August 2006 (Figure 2(b)). However, examination of the synoptic wind fields (not shown) at these levels indicates the existence of another trough axis with lower vorticity over Sudan to the east of Chad, ahead of which the MCSs were observed. At upper levels $(200 \mathrm{hPa})$ the tropical easterly jet (TEJ, associated with winds above $18 \mathrm{~m} \mathrm{~s}^{-1}$ ) observed south of the AEJ was also persistent but underwent a southward displacement from $7.5^{\circ} \mathrm{N}$ to $5^{\circ} \mathrm{N}$.

The MIT C-band Doppler radar at Niamey $\left(13.4915^{\circ} \mathrm{N}\right.$, $2.1698^{\circ} \mathrm{E}, 224 \mathrm{~m}$ ) was operated continuously from July to September with three basic scans performed repetitively over a ten-minute interval. The scanning strategy in each ten-minute cycle was based on a survey longrange $(250 \mathrm{~km})$ azimuthal (conical) scan at a unique low elevation angle $\left(0.7^{\circ}\right)$, followed by a volume exploration composed of 15 shorter-range $(150 \mathrm{~km})$ conical scans at the respective elevation angles of $0.57^{\circ}, 1.36^{\circ}, 2.06^{\circ}$, $2.88^{\circ}, 3.97^{\circ}, 4.96^{\circ}, 6.28^{\circ}, 7.59^{\circ}, 9.17^{\circ}, 11.16^{\circ}, 13.59^{\circ}$, $16.48^{\circ}, 19.97^{\circ}, 24.17^{\circ}$ and $29.3^{\circ}$. Optional RHI (range height indicator) scans were then performed at any
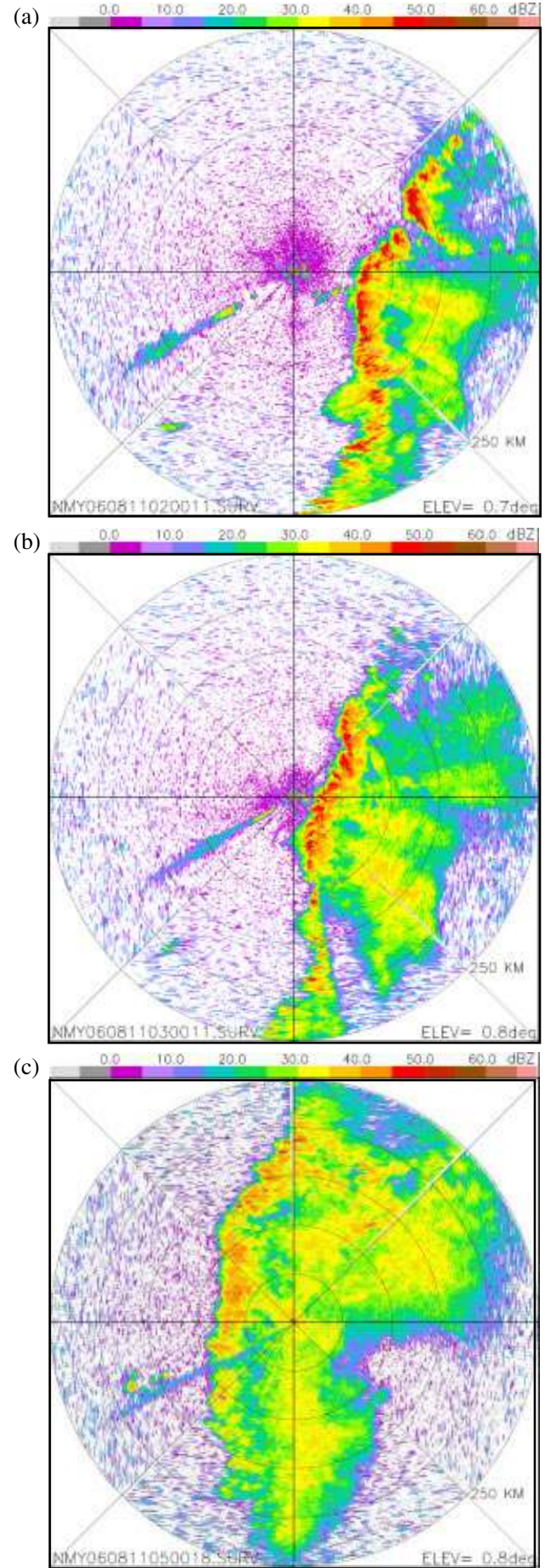

Figure 3. PPI representation of radar reflectivity (dBZ) at $0.7-0.8^{\circ}$ elevation and (a) 0200, (b) 0300, (c) 0500 UTC 11 August 2006, observed by the C-band MIT Doppler radar installed at Niamey (Niger) within a $250 \mathrm{~km}$ range. Survey mode, see text. This figure is available in colour online at www.interscience.wiley.com/journal/qj

azimuth and range of potential interest. Figure 3 presents the classic PPI (plan position indicator) representation of the radar reflectivity field from the survey mode at 0200,0300 and 0500 UTC. It shows the early-tomature precipitation system composed of a north-south oriented line of convective cells $(>45 \mathrm{dBZ})$ and a wide region of stratiform precipitation $(25-40 \mathrm{dBZ})$, both separated by the transition zone of lighter rain $(<25 \mathrm{dBZ}$ : 
Biggerstaff and Houze, 1991). This leading line was not fully rectilinear, but presented an eastward deflection by $30^{\circ}-35^{\circ}$ in its northern portion where more extensive stratiform precipitation occurred. Figure 3(c) indicates that the squall-line system had a width of $300 \mathrm{~km}$ to the north and $200 \mathrm{~km}$ to the south. The convective line was located at $60 \mathrm{~km}$ to the east of the radar at 0200 UTC and progressed mainly westward before it arrived at the radar site at 0320 UTC, and then moved toward the northwest in a way consistent with the mid-level AEJ orientation discussed above. The RHI scan performed at 0209 UTC and $110^{\circ}$ azimuth (Figure 4) reveals a wellmarked forward anvil and trailing stratiform precipitation area on either side (left and right, respectively) of the convective precipitation region (at a distance between 45 and $90 \mathrm{~km}$ ) and echo top at about $15 \mathrm{~km}$ altitude. Note also the layer of maximum reflectivity (30-35 dBZ) near $4 \mathrm{~km}$ altitude, in the stratiform rain region to the rear of the convective line, which reflects the bright band although it was not well organized at this time of the squall-line development.

Figure 5 shows the environmental (temperature and wind) conditions obtained from the sounding at 2331 UTC on 10 August 2006 made by the Atmospheric Radiation Measurement (ARM) mobile facility (AMF) at Niamey airport. The thermodynamic profile exhibits a relatively unstable atmosphere with a convective available potential energy (CAPE) of $2290 \mathrm{~J} \mathrm{~kg}^{-1}$ according to an irreversible (pseudoadiabatic) process and a convective inhibition of $-63 \mathrm{~J} \mathrm{~kg}^{-1}$. These values are associated with a lifting condensation level (LCL) and a level of free convection (LFC) at respectively $892 \mathrm{hPa}$ and $822 \mathrm{hPa}$, along with a wet-bulb potential temperature of nearly $25^{\circ} \mathrm{C}$ (Figure 5(a)). The CAPE value is quite consistent with a change of irreversible CAPE of about $1000 \mathrm{~J} \mathrm{~kg}^{-1}$ when the boundary-layer wet adiabat is in excess of $1{ }^{\circ} \mathrm{C}$ with respect to the typical tropical zero-CAPE intercept of wetbulb temperature $\left(23^{\circ} \mathrm{C}\right)$ as found by Williams and Renno (1993). The environmental air at low-to-middle levels $(<560 \mathrm{hPa})$ was relatively humid $(70 \%-90 \%)$ and was topped by a deep layer (between $500 \mathrm{hPa}$ and $240 \mathrm{hPa}$ ) of dry air $(10 \%-50 \%)$. The $0^{\circ} \mathrm{C}$ isotherm was located at $575 \mathrm{hPa}(4.6 \mathrm{~km})$. Figure $5(\mathrm{~b})-(\mathrm{c})$ shows that the environmental winds were dominated by the west-east component within the three characteristic dynamical layers, i.e. the low-level $(<1.2 \mathrm{~km})$ monsoon layer, the mid-level (3-5.5 km altitude) AEJ layer and the upperlevel (above $10 \mathrm{~km}$ altitude) TEJ layer. These three layers had smaller southerly, northerly and southerly wind components, respectively. The west-southwesterly monsoon moist flow and AEJ had peak intensities of 8 $\mathrm{m} \mathrm{s}^{-1}$ and $15 \mathrm{~m} \mathrm{~s}^{-1}$, respectively, while the well-defined TEJ contained a peak value of $22 \mathrm{~m} \mathrm{~s}^{-1}$ around $12 \mathrm{~km}$ altitude. This flow configuration clearly reveals a relatively strong low-level shear $\left(\approx-7 \times 10^{-3} \mathrm{~s}^{-1}\right)$ between $0.25 \mathrm{~km}$ and $3 \mathrm{~km}$ altitude and a weak upper-level shear $\left(\sim 10^{-3} \mathrm{~s}^{-1}\right)$ between $4 \mathrm{~km}$ and $9.5 \mathrm{~km}$ altitude. The existence of this noticeable low-level shear may have favoured the squall-line formation (Rowell and Milford, 1993), while the weak upper-level shear may have contributed to the formation and extent of a trailing stratiform rain region (Schumacher and Houze, 2006). According to these authors, some upper-level shear favours stratiform rain production and maintenance by advecting upper-level hydrometeors (originating in deep convective cells) which are essential to the continued growth of the stratiform cloud. However, too strong a shear could cause the advective transport to occur beyond the stratiform rain area, resulting in less stratiform rain.

\section{Data analysis}

\subsection{Radar-derived winds}

The MIT radar volume scan data are used to infer the 3D airflow and precipitation structure associated with the convective system. The corresponding azimuthal and radial resolutions were of $1^{\circ}$ and $250 \mathrm{~m}$, respectively, while the Nyquist velocity was $12.75 \mathrm{~m} \mathrm{~s}^{-1}$, and a complete volume exploration lasted around $7 \mathrm{~min} 30 \mathrm{~s}$. Due to this relatively small Nyquist velocity, aliased Doppler velocity was observed, and a delicate data preprocessing was dedicated to the correction of the aliasing effects using a method (not described here) adapted from Zhang and Wang (2006). The derivation of the 3D wind field follows the two-step procedure described in Chong et al. (2000). The first step consists of the multipleDoppler synthesis and continuity adjustment technique (MUSCAT: Bousquet and Chong, 1998) in its version adapted to ground-based radars (Chong and Bousquet, 2001). MUSCAT provides a simultaneous solution of the three Cartesian wind components from at least a pair of Doppler observations. In the present context, the MIT

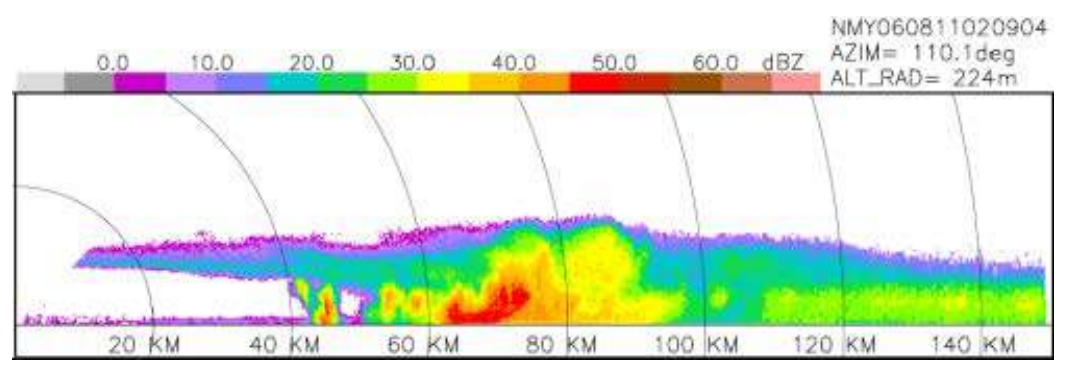

Figure 4. Radar reflectivity (dBZ) in a vertical cross-section (RHI scan) along the azimuth of $110^{\circ}$, and at 0209 UTC 11 August 2006 . This figure is available in colour online at www.interscience.wiley.com/journal/qj 

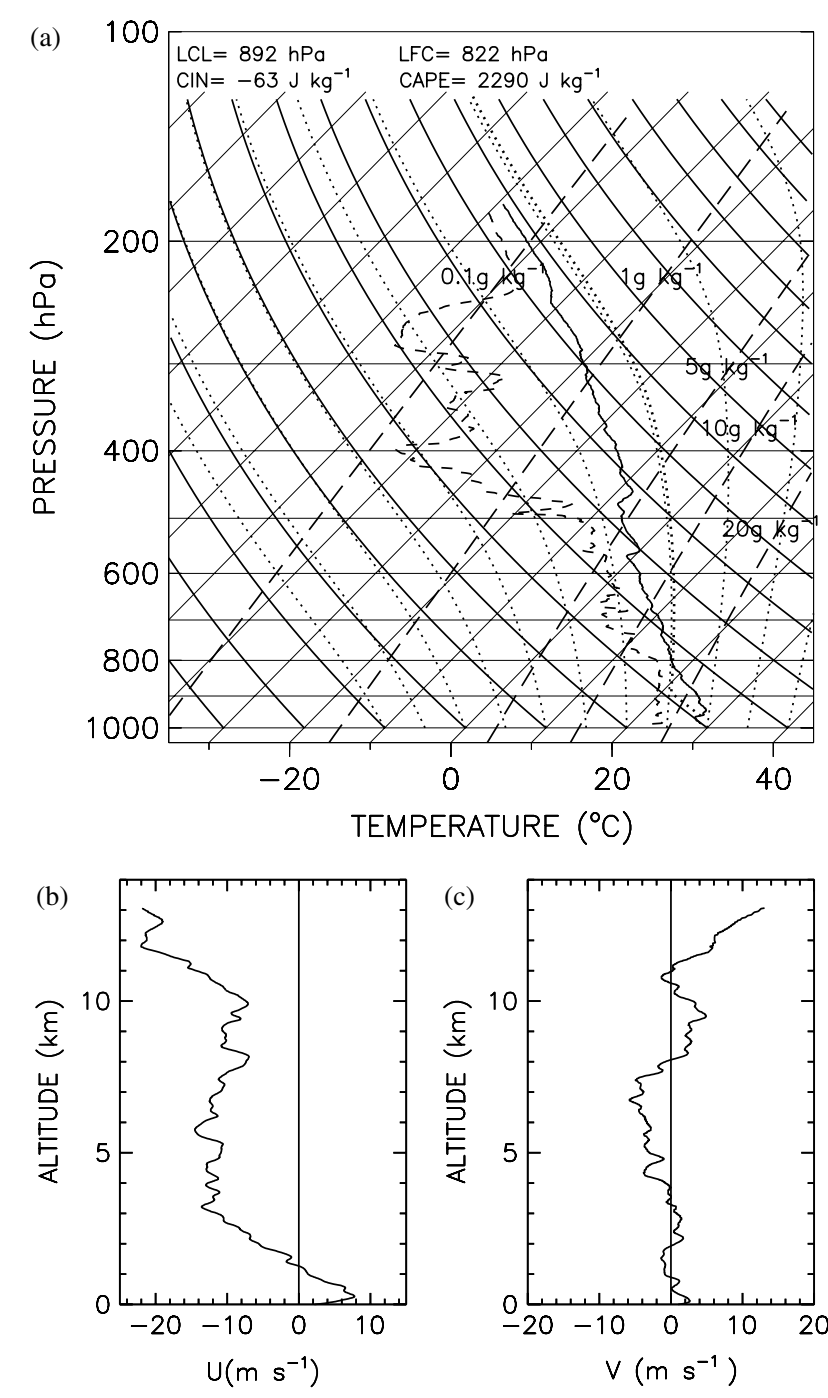

Figure 5. Environmental conditions from ARM sounding launched at Niamey (Niger) at 2331 UTC 10 August 2006: (a) Skew T$\log p$ diagram; (b) Height profile of west-east $(U)$ wind component; (c) Height profile of south-north $(V)$ component.

single-radar data at two or more observation times can be transformed as pseudo dual- or multiple-radar observations as long as temporal variations of the airflow and precipitation structures are dominated by advective processes (steady-state hypothesis). This is accomplished by considering a reference frame moving with the system in which these temporal variations are minimized (Chong et al., 1983). Such an approach has been previously used (e.g. Bluestein and Hazen, 1989; Klimowski and Marwitz, 1992; Bluestein et al., 1994). The advective procedure involved includes, for the same time, radar position, reflectivity and Doppler velocity vector. MUSCAT involves a least squares fit of the observed Doppler velocities to the three Cartesian wind components (including a Cressman distance-dependent weighting function) and of the anelastic continuity equation expressed for either flat (the present study) or complex terrain (Chong and Cosma, 2000), along with a low-pass filtering constraint. In the case of a ground-based dual-radar system,
Chong and Bousquet (2001) proposed to use an additional constraint minimizing the cross-baseline variations of the wind components normal to the radar baseline so as to reduce their geometry-induced errors found to be inversely proportional to the sine of the difference $(\alpha)$ in azimuthal viewing angles at each grid point. Such a constraint is applied with a weight prescribed as $\cos ^{4} \alpha$ (not formulated in Chong and Bousquet, 2001), which is maximum along the baseline $\left(\alpha=0^{\circ}\right)$ where the wind synthesis is ill conditioned, and decreases from 0.5 to 0 if the so-called dual-Doppler lobes of reasonable errors are defined by $33^{\circ}<\alpha<90^{\circ}$. Because the use of more than two single-radar volume data in an advective positioning process is equivalent to having a multiple-radar dataset from radars disposed along a straight baseline, this additional constraint is defined by considering only the two farthest advected radar positions on this line.

However, the MUSCAT-derived wind field does not necessarily verify the mass continuity equation at each grid point because of the least-squares formulation. Therefore a second step in the wind analysis is designed to provide an a posteriori estimation of the vertical velocity obtained through an upward integration of the continuity equation, using a free-slip tangential velocity at the surface (i.e. zero vertical velocity for the present flat terrain) and the previously retrieved horizontal wind components. To overcome the inherent numerical instability of this upward integration due to divergence error accumulation and density stratification, the second analysis step includes the variational approach proposed by Georgis et al. (2000). This consists in correcting the MUSCATderived horizontal wind components so as to minimize the horizontal gradients of the estimated vertical velocity within the 3D analysis domain and the vertical velocity at the upper boundary.

The wind retrieval techniques have been tested with analytical wind fields used to simulate dual-Doppler observations in Bousquet and Chong (1998) and horizontal wind components in Georgis et al. (2000). Considering a radar statistical error of $1 \mathrm{~m} \mathrm{~s}^{-1}$ in the Doppler velocity, Bousquet and Chong (1998) found that errors in the MUSCAT-derived horizontal components could be lower than $0.5 \mathrm{~m} \mathrm{~s}^{-1}$ at any height level. On the other hand, Georgis et al. (2000) found an r.m.s. value of $0.5 \mathrm{~m} \mathrm{~s}^{-1}$ for the errors in the vertical velocity obtained with a random error of $2 \mathrm{~m} \mathrm{~s}^{-1}$ in the horizontal wind components. However, this 3D wind synthesis from singleDoppler radar observations at two instants may suffer from severe drawbacks introduced by the two interrelated hypotheses of steady state and constant propagation of the storm, as discussed in Klimowski and Marwitz (1992) and Bluestein et al. (1994). In fact, the time period of the analysis with no significant structural changes and the advection speed should be such that the resultant radar baseline is sufficiently long to allow a minimum difference in azimuthal viewing angles of $30^{\circ}$ and $20^{\circ}$ for convective and mesoscale motions, respectively (see Bluestein et al., 1994). By comparing dual and pseudodual Doppler analyses, Klimowski and Marwitz (1992) found that the r.m.s. error in wind speed could average 
$30 \%, 60 \%$ and $70 \%$ of the mean wind speed for the optimal gust front, supercell and squall-line analyses with $\alpha>25^{\circ}$, while Bluestein et al. (1994) proposed an interval of $1 \mathrm{~h}$ for an advection speed of $15 \mathrm{~m} \mathrm{~s}^{-1}$ when analysing an MCS having a lifetime of several hours. In this study no attempt was made to infer the analysis errors, due to the absence of a dual-Doppler network. The various constraints in the described wind synthesis are designed to filter out wind irregularities that could eventually modify the shape of the actual wind field and appear as obvious bias, in particular in regions close to the radar baseline (Bousquet and Chong, 1998; Chong and Bousquet, 2001). They are thought to solve the above potential errors which were first addressed through the choice of the analysis time period and the objective determination of the advection speed, as described below.

During the passage of the system over the radar site (between 0330 and 0700 UTC), volume explorations could not be effected (due to data-saving mistakes: Williams, personal communication), leaving only those performed during the approaching phase before 0330 UTC to be potentially available for wind synthesis. This implies that the squall-line motion is along the line of sight of the radar, a situation not very favourable for acceptable $\alpha$ differences to estimate wind components. In this study, the three volume scans starting at 0211, 0241 and 0311 UTC are utilized, under the assumption that the observed precipitation structure remains steady over this one-hour time interval. Figure 6 shows the reflectivity fields at the lowest elevation angle, which appear to be persistent in shape, in particular the leading convective region of higher reflectivity, although considerable changes could be observed in both convective and stratiform rain regions. However, the one-hour period could be considered as sufficiently short for the steady-state assumption with respect to the time-scale of several hours for the MCS overall structure (see Figure 3). The advection velocity components were estimated so that the temporal variations of radar reflectivity in the moving frame were minimum (in the least-square sense), as described in Gal-Chen (1982). The low-level (0.3-3 km layer) reflectivity within the analysis domain (see below) was considered, leading to an advection speed of $13.7 \mathrm{~m} \mathrm{~s}^{-1}$ toward west and $0.5 \mathrm{~m} \mathrm{~s}^{-1}$ toward south, and advected radar positions at 0211 and 0311 UTC located $25 \mathrm{~km}$ on either side of the 0241 UTC position, along the mainly east-west propagation axis. This layer is considered so as to provide a mean advection speed of the main rain features well below the melting level while avoiding potential contamination of the measured reflectivity by ground clutter echo. The wind field retrieval was performed within a domain of $120 \times 150 \times 16 \mathrm{~km}^{3}$, with horizontal and vertical resolutions of $2 \mathrm{~km}$ and $0.5 \mathrm{~km}$ (first level at $0.5 \mathrm{~km}$ altitude), respectively. The Cressman weighting function involved in the data fit process had horizontal and vertical radii of influence of $2 \mathrm{~km}$ and $1.2 \mathrm{~km}$, respectively. The analysis domain is marked as a dashed rectangle in Figure 6 for each observation time and according to the above-discussed moving frame. In the following the Cartesian coordinate system attached to
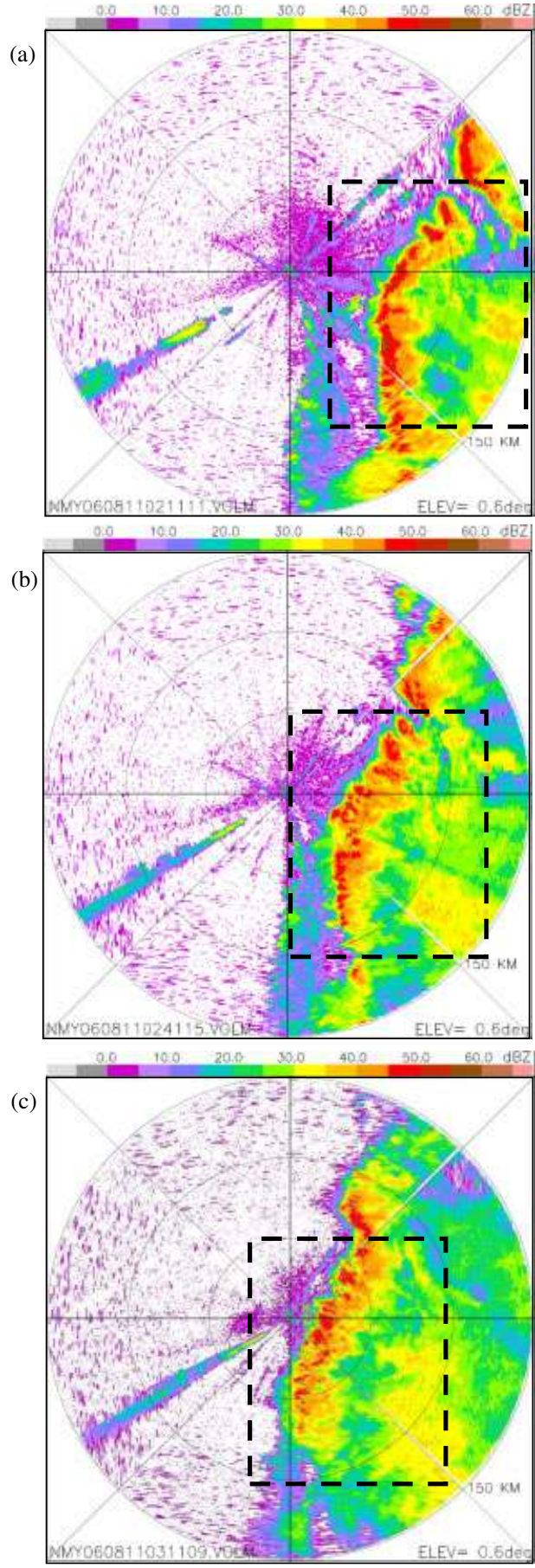

Figure 6. PPI representation of radar reflectivity (dBZ) at $0.6^{\circ}$ elevation and (a) 0211, (b) 0241, (c) 0311 UTC 11 August 2006, observed by the C-band MIT Doppler radar within the $150 \mathrm{~km}$ range of the volume scans. The dashed rectangle embedding a large portion of the convective system represents the data domain for wind field retrieval taking account of an apparent westward advection of the precipitation (see text). This figure is available in colour online at www.interscience.wiley.com/journal/qj

the radar observations at the reference time (Figure 6(b)) will be used, with $x$ - and $y$-axes pointing toward east and north, respectively, and the origin $(0,0)$ at the radar site. It should be noted that the analysis domain includes lowlevel $(<2 \mathrm{~km})$ clear-air echo regions $(<5 \mathrm{dBZ})$ ahead of the convective line at a range of $45-50 \mathrm{~km}$ around the 
radar, convective and transition regions, and a portion of the stratiform region. This clear-air echo was associated with the dust raised in the corridor between the gust front ahead of the squall line and the leading line itself (Williams, personal communication). ARM surface measurements (not shown) clearly identify the gust-front signature (rapid changes in wind speed and direction) at 0316 UTC accompanied by changes in visibility, before the rain arrived at 0332 UTC. Maximum wind was from $110^{\circ}$ with an intensity of $11.3 \mathrm{~m} \mathrm{~s}^{-1}$.

3.2. One-dimensional thermodynamic and microphysical retrieval

Thermodynamic and microphysical retrieval models based upon parametrized microphysical processes and using input data from radar-derived winds and a preconvective thermodynamic profile have been described in previous studies (e.g. Hauser et al., 1988; Marécal et al., 1993; Braun and Houze, 1994). In these studies the thermodynamic equation and the conservation equations for each category of water substance (vapour, cloud and precipitation in liquid and solid phase) were solved in a stationary $2 \mathrm{D}$ context. This $2 \mathrm{D}$ approach is used in the companion paper by Risi et al. (2009) but with simplified microphysical processes. However, Braun and Houze (1995a) noted that the steady-state assumption could better apply to area-mean retrieved variables in a one-dimensional approach, but not at all grid points in the case of a $2 \mathrm{D}$ or $3 \mathrm{D}$ retrieval. In this study, the wind field is obtained from radar observations collected over 1 hour, so the hypothesis of stationarity is less restrictive for its area-mean components. In the following, the 1D formulation of the retrieval as proposed by Braun and Houze (1995a) will be used to diagnose the hydrometeor profiles from a vertical profile of area-mean vertical velocity. The convective and non-convective (transition and portion of stratiform) regions as defined in section 4 will be separately analysed, owing to their dynamically different nature which has key implications for the microphysical development.

As in Marécal et al. (1993) and Braun and Houze (1995a), equations of conservation for water substance including rain $\left(q_{\mathrm{r}}\right)$, graupel-type precipitating ice $\left(q_{\mathrm{g}}\right)$, cloud ice $\left(q_{\mathrm{i}}\right)$ and total water $\left(q_{\mathrm{t}}\right)$ mixing ratios are considered in the retrieval model while mixing ratios of water vapour $\left(q_{\mathrm{v}}\right)$ and cloud water $\left(q_{\mathrm{c}}\right)$ are diagnosed from the retrieved quantities and the saturation water vapour $\left(q_{\mathrm{vs}}\right)$ mixing ratio. The $1 \mathrm{D}$ (in the vertical direction) formulation for these equations (Braun and Houze, 1995a) is completed by the 1D equation for the potential temperature $(\theta)$, and includes parametrization of the horizontal mean flux through the boundary of the averaging domain by approximating average boundary value as a proportion $(90 \%$ and $100 \%$ in convective and non-convective regions, respectively) of the retrieved in-cloud mean value. The microphysical source/sink terms are those detailed in Marécal et al. (1993), based on bulk microphysical parametrizations of Kessler (1969), Lin et al. (1983) and Rutledge and Hobbs $(1983,1984)$ on graupel-type precipitating ice. The microphysical processes involve the autoconversion of cloud water (PRAUT), the accretion of cloud water by rain $(P R A C W)$, the evaporation of rain (PREVP), the initiation of cloud ice $(P I N T)$, the collection of rain by cloud ice (PIACR), the depositional growth or sublimation of cloud ice (PDEPI), the melting of cloud ice (PSMLTI), the autoconversion of cloud ice (PGAUT), the accretion of cloud ice by graupel (PGACI), the riming or accretion of cloud water by graupel $(P G A C W)$, the accretion of rain by graupel $(P G A C R)$, the depositional growth or sublimation of graupel $(P G D E P)$, the melting of graupel (PGMLT), the evaporation of melting graupel (PMLTGE), the accretion of cloud water by melting graupel $(P G A C W M)$, and the accretion of rain by melting graupel $(P G A C R M)$. Accordingly the thermodynamic source term is associated with the exchanges of latent heat from the above microphysical processes and also during the cloud water condensation (evaporation) in saturated updraughts (downdraughts). In this study, exponential size distributions used for rain and graupel both have an intercept parameter of $4 \times 10^{6} \mathrm{~m}^{-4}$, and density of graupel particles (assumed to be nearly spherical) is set to $0.4 \mathrm{~g} \mathrm{~cm}^{-3}$, as in Hauser et al. (1988) and Chong and Hauser (1989). The parameters for graupel are those specified in Rutledge and Hobbs (1984), with the fall-speed-diameter relation for lump graupel given by Locatelli and Hobbs (1974). Finally, with boundary conditions specified for each of the considered variables (see section 5), solutions for the set of microphysical and thermodynamic equations are obtained by using the successive over-relaxation method (Young, 1954).

\section{Airflow and precipitation structure}

Figure 7 shows the deduced airflow and reference (0241 UTC) precipitation field in various horizontal (left) and vertical (right) cross-sections. The horizontal crosssections (Figure 7(a)-(c)) include the system-relative wind vectors and reflectivity pattern (colour shading) at $0.5 \mathrm{~km}, 3 \mathrm{~km}$ and $7 \mathrm{~km}$ altitude, respectively. Vertical cross-sections (Figure 7(d)-(f)) are west-east (along $x$ ) sections of these fields averaged in the along-line direction within the respective $y$-intervals $[-10,10 \mathrm{~km}],[-30$, $-10 \mathrm{~km}]$, and $[-80,-30 \mathrm{~km}]$. According to the low-level reflectivity pattern (Figure 7(a)) and in order to preserve the width of the convective line, the averaging is performed obliquely along the northeast $\left(35^{\circ}\right)$ direction for the northernmost cross-section (Figure 7(d)), while it is along the north-south $y$-direction for the southern sections (Figure 7(e) and (f)). These detailed vertical sections reveal that the domain of analysis mainly contains the convective circulation and precipitation whereas only a portion of the stratiform precipitation is observed. The resemblance of the airflow in these sections suggests the predominance of cross-line circulation and reflects the two-dimensional character of squall lines, although alongline variations exist. 

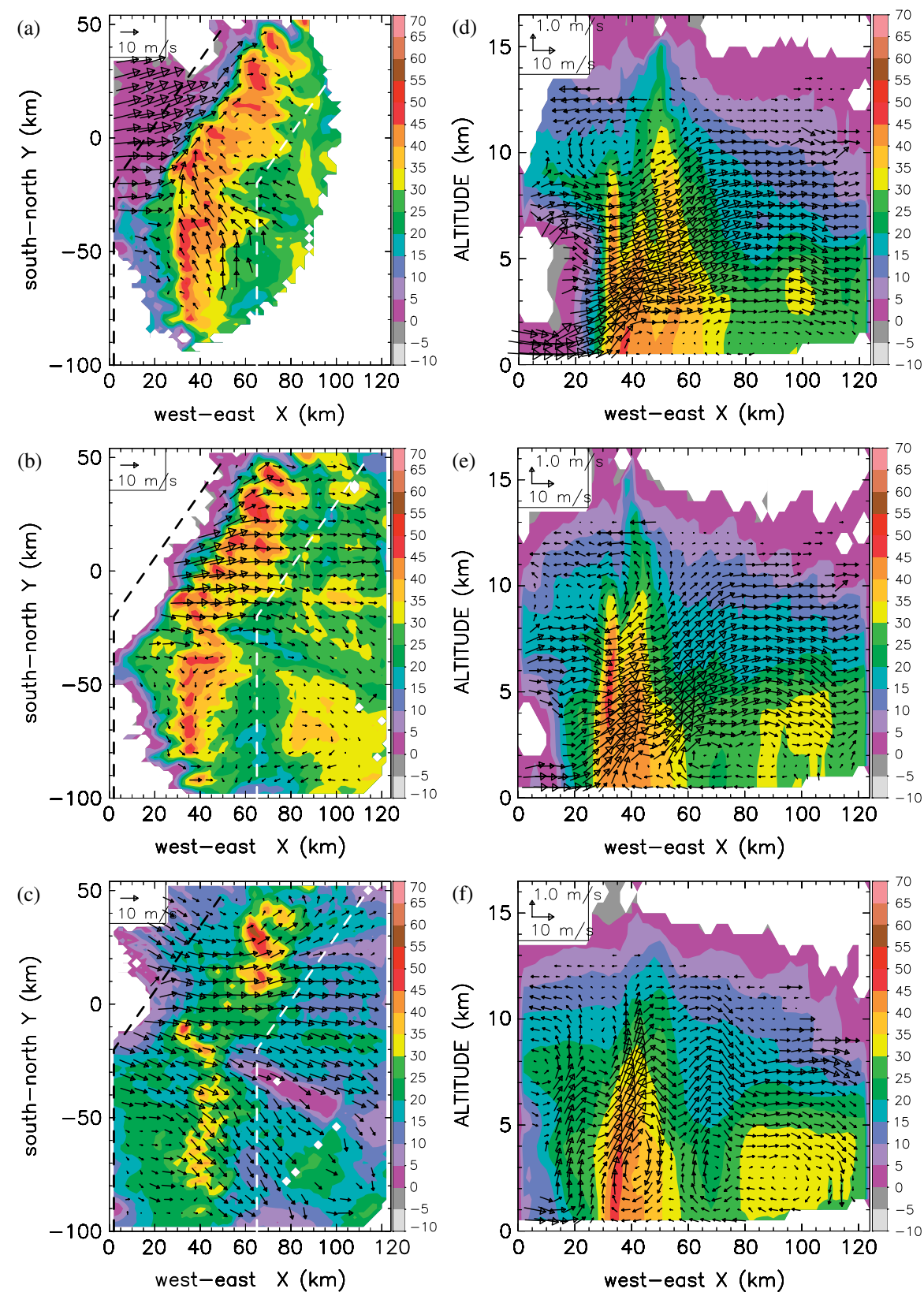

Figure 7. Horizontal cross-sections of (every third) system-relative wind vector and reflectivity pattern at (a) $0.5 \mathrm{~km}$, (b) $3 \mathrm{~km}$, and (c) $7 \mathrm{~km}$ altitude, and west-east (cross-line $x$ ) vertical cross-sections of winds (every other vector along $x$ ) and reflectivity averaged along the line at $y$ ranges of (d) $[-10,+10 \mathrm{~km}],(\mathrm{e})[-30,-10 \mathrm{~km}]$, and (f) $[-80,-30 \mathrm{~km}]$, from north to south, respectively. Wind vector scaling is indicated in the upper left corner of each panel, while reflectivity (dBZ) scaling is on the right side. The analysis boxes of the horizontal sections are identical with the rectangular region in Figure 6, and the coordinate system refers to the radar frame at 0241 UTC in Figure 6(b). Dashed vertical and oblique lines in (a)-(c) delimit the regions of convective (between black and white lines) and stratiform (to the east of white line) precipitation. This figure is available in colour online at www.interscience.wiley.com/journal/qj

The system-relative convective airflow structure reveals features commonly observed in squall-line systems or reported in conceptual models (e.g. Zipser, 1977; Gamache and Houze, 1982; Chong et al., 1987; Houze et al., 1989; Caniaux et al., 1994), which support the validity of the MUSCAT technique applied to a series of advection-corrected single-Doppler radar scans. These are (1) the low-level front-to-rear flow ahead of the convective cells (western side) opposing the rear-to-front (eastern side) flow mainly concentrated in the southern part of the domain (Figure 7(a)), (2) the sloping leading convective updraughts resulting from these convergent flows and which could reach $4 \mathrm{~m} \mathrm{~s}^{-1}$ and transport unstable low-level air up to $10-13 \mathrm{~km}$ altitude (Figure 7(c)-(f)) where apparent frontward and rearward diverging outflows occur as a manifestation of the detrainment of the updraught air, (3) the convective-scale downdraught (reaching $-2.6 \mathrm{~m} \mathrm{~s}^{-1}$ ) within the heavy precipitation region (Figure 7(f); see also Risi et al., 2009) and contributing to the low-level rear-to-front flow associated with a cold pool, and (4) the overall front-to-rear flow at mid-to-upper levels incorporating updraught or downdraught, or passing through the cells (Figures 7(b)-(f)). The diverging aspect of this flow in the upper levels in 
regions of active cells is also indicative of convectiveupdraught outflow. To the rear of the convective region (roughly beyond $x=70 \mathrm{~km}$ in Figure 7(d)-(f)), the transition region and the portion of the stratiform area are associated with lighter upward and downward motions at mid-to-upper and lower levels, respectively, as contributing to the mesoscale updraught and downdraught. Note also that the upper level frontward and rearward outflows are well consistent with the marked forward and trailing anvils as observed in the RHI scan shown in Figure 4.

As a key element of the Sahel squall lines, the gust front associated with the rear-to-front outflow can be easily characterized in Figure 8 which displays the absolute winds at the lowest retrieved level. Figure 8 shows that the cold easterly outflow from the convective system could progress ahead of the leading edge into the region of warm southwesterly inflow air and caused the dust lifting. Evidence of the dusty gust front as a density current issued from an MCS over southwest Niger during the SOP can be also found in Bou Karam et al. (2008). A topic of considerable interest is the fate of the dusty air, necessitating further investigation beyond the scope of this study. Its transport to the ITD is probable, but this would require a gust front propagation well northward. It could also be entrained in the squall line and ultimately transferred to ground in the rain. In their analysis of aerosol properties measured during the AMMA SOP and associated with the passage of an MCS over the region of Niamey, Crumeyrolle et al. (2008) found that mineral dust generated by the MCS gust front could mix with gas and aerosols contained in the monsoon flow. The vertical cross-sections (Figure 7(d)-(f)) suggest that the buoyant inflow air could entrain some of the dust from the gust front.

The predominance of inflow that penetrated inward within the northern part of the squall-line (see Figure 7(a), (b), (d) and (e)) and the absence of marked lower-level rear-to-front flow (Figure 7(a)) probably contributed to the rearward deflection of the leading line. The more extensive stratiform precipitation observed in Figure 3(c) could be related to this deep and pronounced layer of

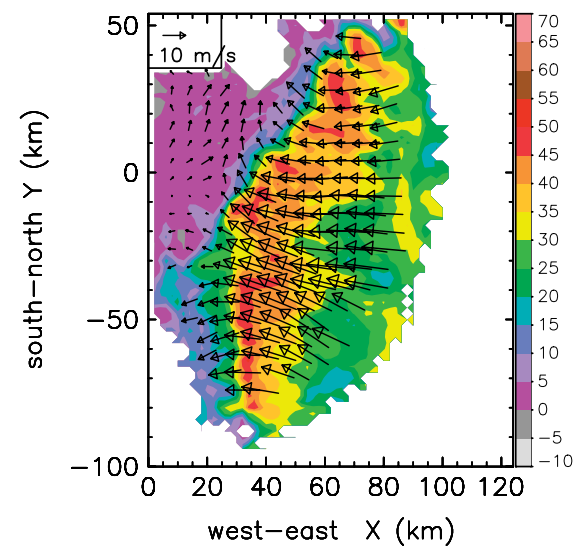

Figure 8. Horizontal cross-section of (every third) absolute wind vector and reflectivity pattern at $0.5 \mathrm{~km}$ altitude. This figure is available in colour online at www.interscience.wiley.com/journal/qj rearward flow as revealed in Figure $7(\mathrm{c})-(\mathrm{d})$, which helped small and/or light hydrometeors detrained from the convective cells to be advected farther downwind before they fell out (Biggerstaff and Houze, 1991). The inflow at middle level $(3-7 \mathrm{~km})$ accelerated inward as it approached and incorporated the convective cells, while the lower-level (below $2 \mathrm{~km}$ ) layer of potentially unstable air fed the sloping convective updraughts, according to the 'layer lifting' concept reviewed by Houze (2004), which consists of an ascending layer on a slantwise path through the convective system in the presence of strong environmental low-level wind shear and promotes formation of a broad region of stratiform cloud.

Figure 9 presents the mean flow characteristics within the convective and transition-stratiform (TS) regions. The area between the black and white dashed lines reported in Figure 7 roughly delimits the convective region, while that on the right side contains the TS region. The mean relative west-east (cross-line $U$ ) velocity component (Figure 9(a); parallel to the $x$-axis) was positive in almost all the troposphere (except at upper levels of the convective region, above $10.5 \mathrm{~km}$ because of the presence of the forward anvil, and low levels of the TS region where a rear-to-front flow could be identified), in a way consistent with the flow structure observed in Figure 7. In the layer between 2.5 and $9 \mathrm{~km}$ where convective updraughts (Figure 9(c)) were maximized (see also Figure 7(d)-(f)), this component was more than twice as large in magnitude as the mean alongline $V$ (parallel to the $y$-axis) component (Figure 9(b)). At $1.5 \mathrm{~km}$ altitude, there was a layer of minimum cross-line wind component in the convective region, which could be attributed to the rear-to-front flow behind the convective line. The mean along-line component in both convective and TS regions was from the south in low and upper levels, and from the north in midtroposphere. With respect to the environmental wind profile (Figure 5(b)-(c)), this along-line component did not present significant changes in contrast to the cross-line component, and the reversal of its direction in mid-levels may be indicative of the existence a large-scale, threedimensional, kinematic structure (Chong et al., 1987). On average, the convective region was associated with upward vertical motions (Figure 9(c)) throughout the troposphere, with a marked maximum $\left(0.4 \mathrm{~m} \mathrm{~s}^{-1}\right)$ around $3 \mathrm{~km}$, while the TS region exhibited small (0.05-0.07 m $\mathrm{s}^{-1}$ ) mesoscale downdraught (updraught) below (above) $7 \mathrm{~km}$ altitude, respectively. This relatively high level of updraught/downdraught separation probably results from the incomplete representation of the extensive stratiform region in the radar analysis.

Using an idealized MCS, Yang and Houze (1996) found that the momentum redistribution through vertical fluxes in the convective region is important in increasing rearward momentum in the middle levels, and it combines with the buoyancy-induced pressure gradient force. To analyse the role of the convective transports on the observed internal flow structure, mean and eddy momentum transports within the same area defined above for the mean convective flow are presented in Figure 10. 

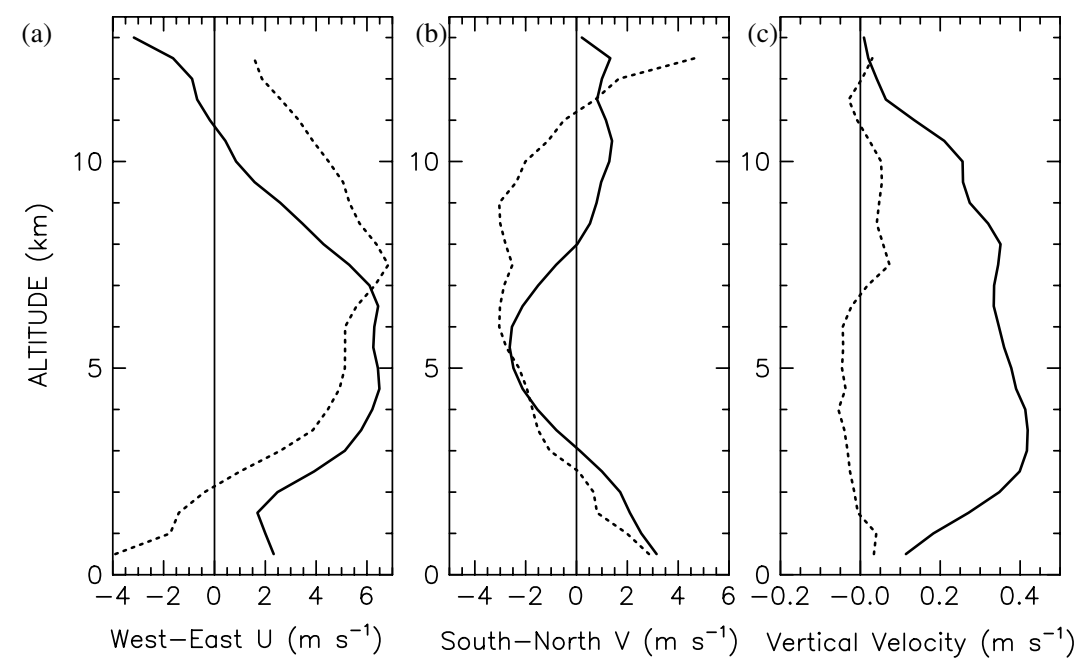

Figure 9. Height profiles of Cartesian wind components, averaged over the convective (solid lines) and transition-stratiform (dotted lines) regions represented on the left-hand side of Figure 7: (a) west-east $U$ component (positive eastward); (b) south-north $V$ component (positive northward); (c) vertical velocity $W$.

The area-mean vertical flux of relative cross-line momentum $(\rho \overline{U W}$ in Figure 10(a)) was positive over most of the troposphere, with a peak value of $3.7 \mathrm{~N} \mathrm{~m}^{-2}$ at $3.5 \mathrm{~km}$ altitude. Average eddy $U$-momentum vertical fluxes $\left(\rho \overline{U^{\prime} W^{\prime}}\right)$ accounted for less than half the mean total transport at low-to-middle levels $(2-6 \mathrm{~km})$, with peak value of $1.4 \mathrm{~N} \mathrm{~m}^{-2}$ at $3.5 \mathrm{~km}$ altitude, and vanished at upper levels of the observed forward anvil. This non-negligible contribution is consistent with the relative importance of the convective-scale motions at these levels, as discussed above. In contrast, the mean along-line momentum transports $(\rho \overline{V W}$ in Figure $10(\mathrm{~b}))$ were found to be much smaller $\left(<0.8 \mathrm{~N} \mathrm{~m}^{-2}\right.$ in magnitude) than the cross-line transports, with negative values at mid-levels $(3-8 \mathrm{~km})$, while the mean eddy $V$-momentum fluxes $\left(\rho{\overline{V^{\prime} W^{\prime}}}^{\prime}\right)$ were positive over all the troposphere, with, however, negligible intensity. Figure 10(c)-(d), which shows the mean total cross-line and along-line wind accelerations due to advection, respectively, along with the contribution from vertical flux (mean and eddy) convergence, reveals that most of the horizontal momentum exchanges were operating in the vertical direction. The mean vertical flux convergence had a predominant contribution to the total advection-induced tendency for each horizontal wind component. Moreover, the major vertical redistribution of horizontal momentum was achieved for the cross-line component, since the cross-line accelerations were higher than the along-line accelerations, consistent with the predominant 2D structure of squall lines. Eddy cross-line momentum flux convergence accounted for a large proportion (Figure 10(c)) in a deep lower part of the atmosphere $(<7 \mathrm{~km})$, in contrast to the along-line component (Figure 10(d)) which was primarily transported by the mean vertical motion. Negative and positive eddy cross-line vertical flux convergence at lower and middle levels, respectively, again indicate the role of the turbulent motions, removing momentum from low levels and redistributing it to mid-to-upper levels. This situation is quite consistent with previous studies of the momentum redistribution in squall lines (Moncrieff, 1992; Caniaux et al., 1995) in addition to horizontal acceleration by pressure gradient forces (Houze, 2004). Finally, combination of these two processes could yield a net momentum tendency that reinforced the mid-level front-to-rear flow (Caniaux et al., 1995; Yang and Houze,1996), and therefore contributed to increase the size of the observed mesoscale convective system (see Figure 1(c)-(d)), as long as convective sustainability helped to maintain convection (Houze, 2004).

\section{Vertical distribution of microphysical quantities}

In this section, the vertical distributions of the microphysical quantities within the convective and TS regions, as defined above, are diagnosed by considering the vertical velocity profiles of Figure 8(c). Both microphysical and thermodynamic retrievals were performed in the convective region with the input thermodynamic profile shown in Figure 5(a) and corresponding to the nearest environmental conditions. In the TS region, only the microphysical retrieval was applied because the available input sounding launched at 0531 UTC on 11 August 2006 could be assumed as representative of the in-cloud thermodynamic profile. Indeed the relative (advected) position of this sounding in the radar observation picture at the 0241 UTC reference time (Figure 6(b)) would be $140 \mathrm{~km}$ to the east of the radar, say $20 \mathrm{~km}$ farther than the eastern edge of the wind analysis domain.

\subsection{Validation}

In the convective region, the following boundary conditions were used to solve the equations for cloud ice $\left(q_{\mathrm{i}}\right)$, rain $\left(q_{\mathrm{r}}\right)$, graupel $\left(q_{\mathrm{g}}\right)$, total water $\left(q_{\mathrm{t}}\right)$ mixing ratio, and potential temperature $(\theta)$ in the height range of observed mean vertical velocity. At the bottom, $q_{\mathrm{i}}$ and $q_{\mathrm{g}}$ were set to zero, while $q_{\mathrm{r}}$ and $q_{\mathrm{t}}$ were imposed to have constant vertical gradients as in Marécal et al. (1993) and Braun 

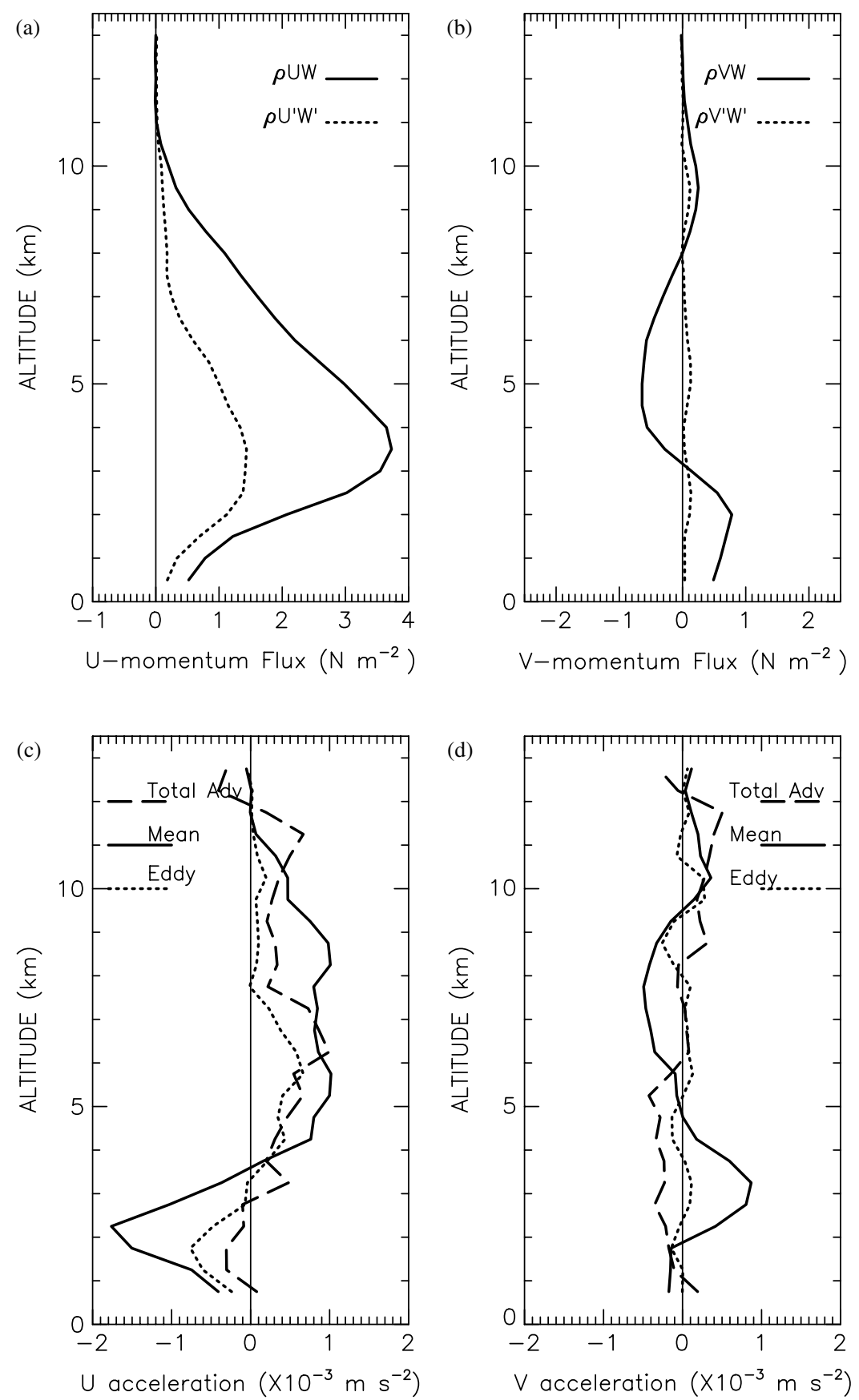

Figure 10. Height profiles of convective domain-averaged vertical flux of (a) relative cross-line momentum (total $\rho \overline{U W}$ and turbulent $\rho \overline{U^{\prime} W^{\prime}}$ ); (b) relative along-line momentum (total $\rho \overline{V W}$ and turbulent $\rho \overline{V^{\prime} W^{\prime}}$ ); (c) cross-line $(U)$ acceleration due to total advection, vertical average and eddy $U$-flux convergence; (d) along-line $(V)$ acceleration due to total advection, vertical average and eddy $V$-flux convergence.

and Houze (1995a), and $\theta$ was assumed to have also a constant vertical gradient. At the top, $q_{\mathrm{i}}$ and $q_{\mathrm{r}}$ were set to zero, $q_{\mathrm{g}}$ was deduced from the observed mean radar reflectivity according to the $q_{\mathrm{g}}-Z$ relationship described in Chong and Hauser (1989), while $q_{\mathrm{t}}$ was the sum of this $q_{\mathrm{g}}$ and initial water vapour mixing ratio $\left(q_{\mathrm{v}}\right)$ deduced from the environmental sounding. The initial potential temperature was set equal to the environmental value. In this study we assumed moreover that cloud ice and graupel did not exist at temperatures greater than $2{ }^{\circ} \mathrm{C}$ (below $4.3 \mathrm{~km}$ ) and $10^{\circ} \mathrm{C}$ (below $3 \mathrm{~km}$ ), respectively, rain was not present at temperature lower than $-20^{\circ} \mathrm{C}$ (above
$8 \mathrm{~km}$ ), and that the potential temperature perturbation (from the observed initial potential temperature) vanished above $10.5 \mathrm{~km}$ altitude in order to obtain a retrieved temperature profile not far from the in-cloud profile at 0531 UTC 11 August 2006. Between these prescribed levels, all the water species were initialized to zero, except $q_{\mathrm{t}}$ which was set equal to the environmental $q_{\mathrm{v}}$. In the TS region, similar boundary and initial conditions were used, but associated with the in-cloud thermodynamic profile.

As a partial validation of the diagnostic model, Figures 11(a) and 11(b)-(c) compare the profiles of the retrieved potential temperature perturbation and of the 

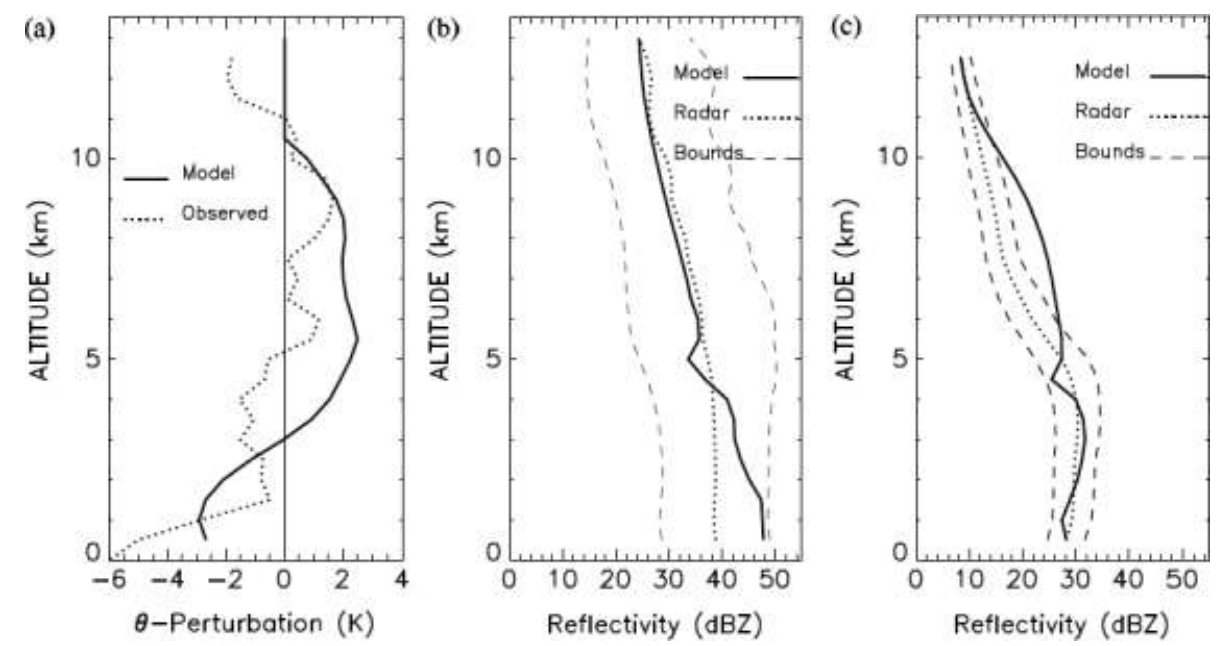

Figure 11. Height profiles of (a) observed and retrieved perturbation of potential temperature (K); (b) observed and retrieved radar reflectivity (dBZ) in the convective region; (c) observed and retrieved radar reflectivity (dBZ) in the transition-stratiform region. Gridded values of observed reflectivity within the domains shown in Figure 7 are averaged on a logarithmic scale $\left(\mathrm{mm}^{6} \mathrm{~m}^{-3}\right)$ and then transformed into dBZ units. The equivalent reflectivity from retrieved rain and graupel mixing ratio in (b) and (c), respectively, is deduced from analytical relationships. In (b) and (c), the thin dashed lines give the lower and upper bounds of the observed radar reflectivity, defined as the linear (dBZ) averaging of absolute deviation from the mean reflectivity at each level of the relevant domain.

equivalent radar reflectivity factor evaluated from the retrieved rain and graupel mixing ratios, respectively with the potential temperature difference between the above-mentioned soundings and the observed domainaveraged radar reflectivity. Equivalent radar reflectivity is computed by using an analytical formulation deduced from the considered exponential size distributions for rain and graupel, with a correction factor applied to graupel in order to take into account the lower dielectric factor of ice particles and expressed as a function of their density (Fovell and Ogura, 1988). Figure 11(a) shows that the magnitude and height variation of the retrieved $\theta$-perturbations do not depart significantly from the observed ones, with positive perturbations above $3 \mathrm{~km}$. There is also a good consistency of the modeldeduced reflectivity with the radar observation in both convective and TS regions, in particular at levels of mixed phases and ice phase above $4 \mathrm{~km}$ for the convective region (Figure 11(b)) and liquid phase below $4 \mathrm{~km}$ for the TS region (Figure 11(c)). It is worth noting that the retrieved reflectivity mostly lies within the lower and upper bounds of the observed radar reflectivity defined by the average absolute deviation from the mean reflectivity, and it is probable that better agreement would be obtained with empirical relationships for reflectivity-mixing ratio. However, there is a systematic positive bias of the retrieved reflectivity with respect to the radar reflectivity (regularly calibrated by a metal sphere) at lower levels in Figure 11(b). This is probably due to the coalescence that strongly depends on the cloud content (see below) which could be prone to errors since it is estimated as a residual. The retrieved rain mixing ratio at $500 \mathrm{~m}$ altitude corresponded to a rain rate of $33.8 \mathrm{~mm} \mathrm{~h}^{-1}$. The 'observed radar reflectivity' accounted for $9.7 \mathrm{~mm} \mathrm{~h}^{-1}$, using the classical Marshall-Palmer relationship. However the modelled values are reasonably consistent with other observations. Averaging ARM precipitation data at the $1 \mathrm{~m}$ level over 50 minutes from the beginning of rain at Niamey (corresponding roughly to the width of the convective domain) leads to rain rates of $12.7 \mathrm{~mm} \mathrm{~h}^{-1}$, while this average rate reached $18.2 \mathrm{~mm}$ $\mathrm{h}^{-1}$ at the $2.5 \mathrm{~m}$ level. The three-hourly precipitation field $\left(0.25^{\circ}\right.$ resolution) centred at $0300 \mathrm{UTC}$, from the Tropical Rainfall Measuring Mission (TRMM) Multisatellite Precipitation Analysis (Huffman et al., 2007), contained several contiguous rain pixels exceeding $25 \mathrm{~mm} \mathrm{~h}^{-1}$ (with a mean value of $28.5 \mathrm{~mm} \mathrm{~h}^{-1}$ ) near Niamey.

\subsection{Convective region}

The height distributions of rain $\left(q_{\mathrm{r}}\right)$, graupel $\left(q_{\mathrm{g}}\right)$, cloud water $\left(q_{\mathrm{c}}\right)$ and cloud ice $\left(q_{\mathrm{i}}\right)$ mixing ratio (Figure 12(a)) reveal that rain extended up to $5 \mathrm{~km}$ altitude while graupel was primarily concentrated above $4 \mathrm{~km}$ altitude, and that the relatively deep layer of cloud water diagnosed between 1 and $8.5 \mathrm{~km}$ was progressively replaced by cloud ice at upper levels $(5-13 \mathrm{~km})$. The variable character of cloud water was likely an effect of its indirect estimation from the other water species. The largest values up to $0.7 \mathrm{~g} \mathrm{~kg}^{-1}$ were found in the lower troposphere $(1.5 \mathrm{~km})$, while cloud ice reached a maximum value of $1.0 \mathrm{~g} \mathrm{~kg}^{-1}$ at $9.5 \mathrm{~km}$ altitude. On the other hand, precipitating liquid (rain) and solid (graupel) substances were diagnosed to reach $1.3 \mathrm{~g} \mathrm{~kg}^{-1}$ at low $(1.5 \mathrm{~km})$ level and $1.2 \mathrm{~g} \mathrm{~kg}^{-1}$ at mid-level $(6 \mathrm{~km})$, respectively. This stratified distribution of nonprecipitating and precipitating particles appears consistent in shape with those reported in Caniaux et al. (1994) for a tropical squall line (vertical profile at the beginning of the stratiform region, their Fig. 25(b)) or Braun and Houze (1995a) for a mid-latitude squall line (mean profile within the convective region diagnosed with their method used in this study, their Fig. 11(d)), with, however, differences 

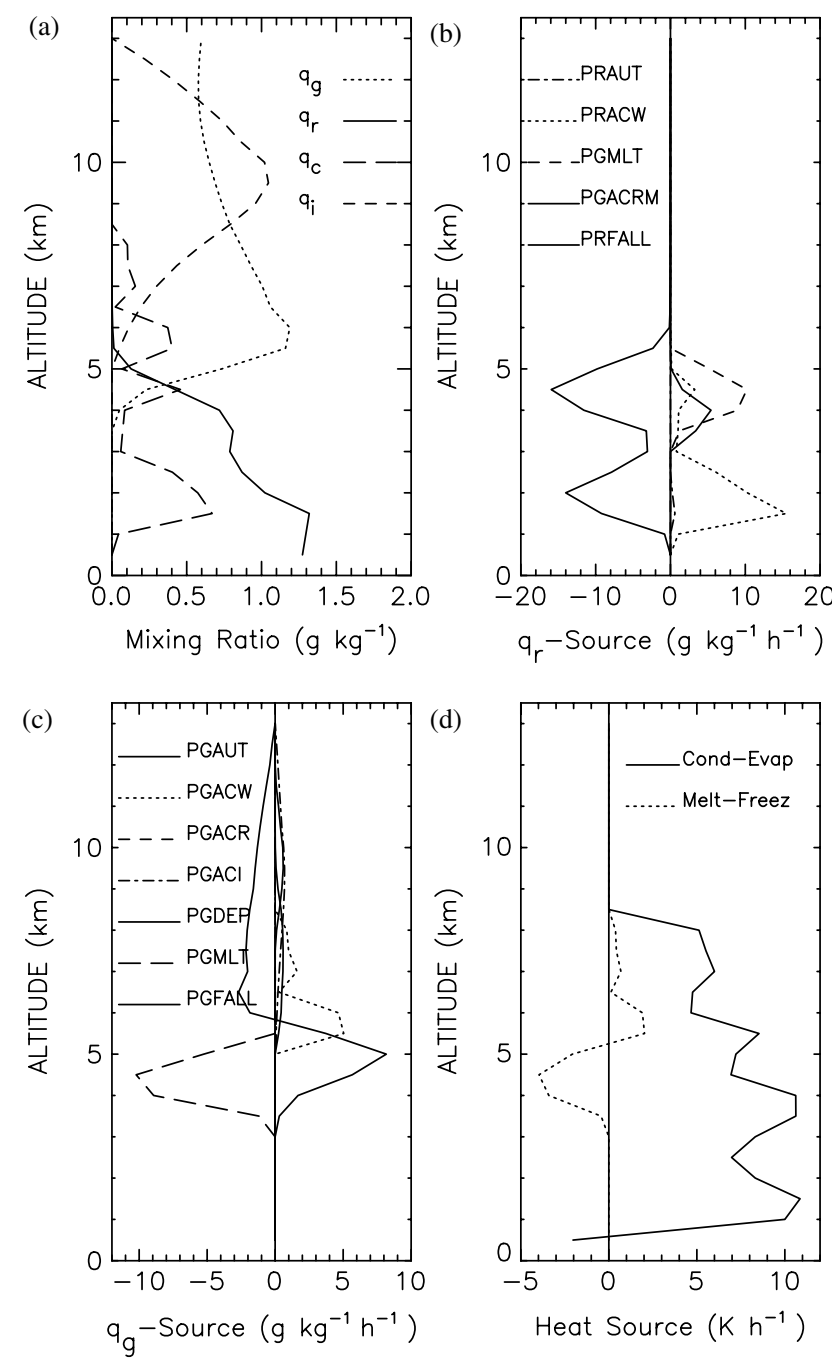

Figure 12. Height profiles of microphysical variables and associated physical processes in the convective region: (a) retrieved mixing ratio $\left(\mathrm{g} \mathrm{kg}^{-1}\right)$ of graupel $\left(q_{\mathrm{g}}\right)$, rain $\left(q_{\mathrm{r}}\right)$, cloud water $\left(q_{\mathrm{c}}\right)$, and cloud ice $\left(q_{\mathrm{i}}\right)$; (b) rain production $\left(\mathrm{g} \mathrm{kg}^{-1} \mathrm{~h}^{-1}\right.$, negative value is a loss term) from autoconversion (PRAUT), cloud water collection (PRACW), melting of graupel (PGMLT), and accretion by melted graupel (PGACRM), along with sedimentation of rain $(P R F A L L)$; (c) graupel production (g $\left.\mathrm{kg}^{-1} \mathrm{~h}^{-1}\right)$ from autoconversion $(P G A U T)$, riming $(P G A C W)$, accretion of rain $(P G A C R)$, accretion of cloud ice $(P G A C I)$, depositional growth $(P G D E P)$, and melting $(P G M L T)$, along with sedimentation of graupel $(P G F A L L)$; (d) latent heat source $\left(\mathrm{K} \mathrm{h}^{-1}\right)$ due to cloud water condensation, cloud and/or rain evaporation, and melting of graupel and cloud water freezing.

in the magnitude owing to the different conditions of the analysed system. In particular both studies show a cloud ice peak nearly three times lower than the predominant graupel mixing ratio peak, the rain mixing ratio peak lying in between. Cloud ice and graupel are of equivalent importance in the present case and they could be conveyed by the flow at upper levels, farther from the leading deep convection to the trailing stratiform region, thereby increasing the precipitation extent.

The main microphysical processes that contributed to the sources or sinks of the precipitation are detailed in Figure 12(b) for rain and Figure 12(c) for graupel. The corresponding fallout terms (PRFALL and PGFALL) are also reported. Coalescence or accretion of cloud water by rain $(P R A C W)$ was the dominant process of rain production below the melting layer $(3.5-5.0 \mathrm{~km})$, while melting of graupel (PGMLT) and to a lesser degree accretion of rain by this melted graupel (PGACRM) also contributed to this formation (Figure 12(b)). Autoconversion of cloud water to form rain (PRAUT) was not a dominant process. Sedimentation of rain (PRFALL) occurred negatively (sink) at all the levels of the rain production so as to reduce it in a large proportion except at low levels $(<1.5 \mathrm{~km})$ of maximized rain. Source and sink terms for graupel (Figure 12(c)) also were not balanced at all levels, in particular at the altitude $(5.5 \mathrm{~km})$ of maximum graupel mixing ratio. Riming or accretion of cloud water by graupel $(P G A C W)$ accounted for the main production process at this level, while positive fallout of graupel (PGFALL) underneath contributed to enhancing the graupel source. Autoconversion of cloud ice to form graupel (PGAUT), accretion of rain by graupel $(P G A C R)$, accretion of cloud ice by graupel (PGACI), and depositional growth of graupel $(P G D E P)$ were very low with respect to $P G A C W$ and $P G F A L L$, but their combined effects at mid-to-upper levels $(5.5-12 \mathrm{~km})$ should compensate the sink of graupel due to sedimentation (negative PGFALL). Due to the occurrence level in the melting layer, the falloutinduced source acted to maintain the sink of graupel by the melting process (PGMLT). Unsurprisingly these main precipitation developments (i.e. riming, melting, coalescence) are those commonly found in squall-line MCSs (Leary and Houze, 1979; Houze and Betts, 1981; Smull and Houze, 1987; Hauser et al., 1988; Chong and Hauser, 1989; Caniaux et al., 1994). Figure 12(d) shows the profiles of latent heating/cooling rates due to cloud water condensation, cloud and/or rain evaporation, melting of graupel particles and cloud water freezing that contribute to the changes in the potential temperature profile of Figure 11(a). Condensation provides the major heat source throughout the deep layer of cloud water, and associated heating rate could reach $10.9 \mathrm{~K} \mathrm{~h}^{-1}$. This source was reduced by the cooling (up to $-4.0 \mathrm{~K} \mathrm{~h}^{-1}$ ) due to melting below $5 \mathrm{~km}$ altitude and increased above by warming (up to $2.0 \mathrm{~K} \mathrm{~h}^{-1}$ ) in the freezing region. The importance of melting and freezing was also diagnosed in mid-latitude and tropical squall lines by Braun and Houze (1995b) and Caniaux et al. (1994), respectively.

\subsection{Transition-stratiform region}

Figure 13 shows the results of the 1D microphysical retrieval in the TS region. The various profiles for each category of water substance (Figure 13(a)), and the processes that contributed to rain and graupel source or sink (Figure 13(b)-(c), including fallout) and latent heat source (Figure 13(d)) dramatically differ from those found in the convective region. Except for the cloud ice content $\left(q_{\mathrm{i}}\right)$, the retrieved quantities are lesser in a proportion quite consistent with the distinct convective and mesoscale vertical motions shown in Figure 9(c).

The mixing ratio profiles for rain $\left(q_{\mathrm{r}}\right)$, graupel $\left(q_{\mathrm{g}}\right)$, cloud water $\left(q_{\mathrm{c}}\right)$ and cloud ice $\left(q_{\mathrm{i}}\right)$ (Figure 13(a)) reveal that cloud ice was predominant at upper levels $(1.1 \mathrm{~g}$ 

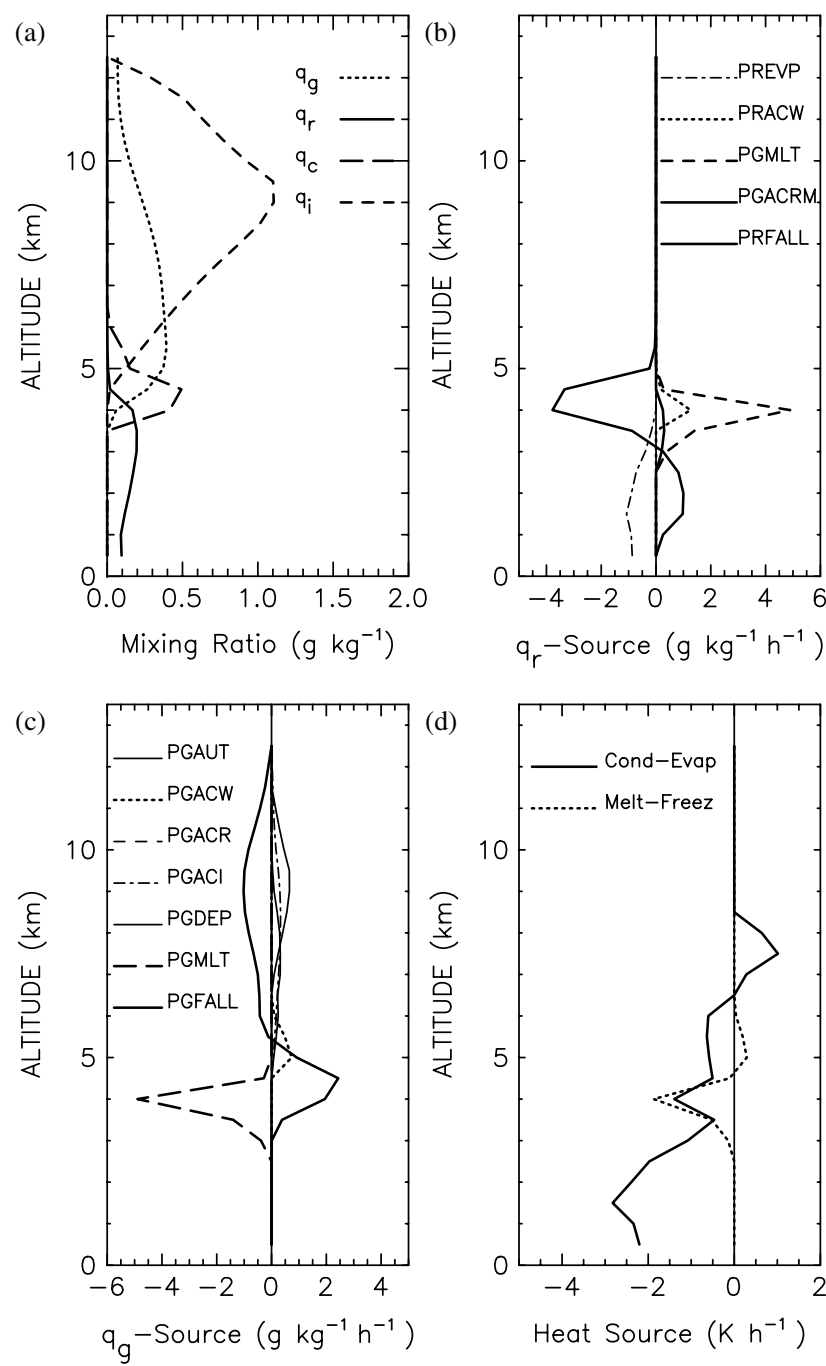

Figure 13. As in Figure 12, but for the transition-stratiform region. In (b), the rain production terms of interest are the cloud water collection (PRACW), melting of graupel (PGMLT), and accretion by melted graupel $(P G A C R M)$, rain evaporation $(P R E V P)$, and sedimentation of rain (PRFALL)

$\mathrm{kg}^{-1}$ at $9 \mathrm{~km}$ altitude) while graupel above $4 \mathrm{~km}$ and rain below $4.5 \mathrm{~km}$ reached 0.4 and $0.2 \mathrm{~g} \mathrm{~kg}^{-1}$, respectively, and cloud water was concentrated in the $3.5-6.5 \mathrm{~km}$ layer with maximum value of $0.5 \mathrm{~g} \mathrm{~kg}^{-1}$. The rain mixing ratio was decreasing from the cloud base level to the surface as an effect of rain evaporation in the subsaturated downdraught.

In contrast to the convective region, the melting of graupel (PGMLT) was the main rain source in this TS region, with small contributions of coalescence $(P R A C W)$, as shown in Figure 13(b). Rain sedimentation (PRFALL) positively (negatively) contributed to the rain source below (above) $3 \mathrm{~km}$ altitude (Figure 13(b)) while rain evaporation (PREVP) tended to offset it. As for the graupel source, Figure 13(c) shows height variations of the various microphysical processes similar to those found in the convective region, but with reduced values. Peak source from graupel sedimentation (PGFALL) and sink from melting (PGMLT) occurred at 4.5 and $4 \mathrm{~km}$ altitude, respectively, and they largely dominated the graupel production due to riming at $5 \mathrm{~km}$. Again contrary to the convective region, cooling due to cloud and rain evaporation and melting was the major induced effect up to $6.5 \mathrm{~km}$ altitude, above which heating was provided by condensation (Figure 13(d)). Evaporative cooling occurring below $3 \mathrm{~km}$, was maximized in the layer of unsaturated rear-to-front flow (see Figure 9(a)), reaching $-2.8 \mathrm{~K}$ $\mathrm{h}^{-1}$ at $1.5 \mathrm{~km}$, while melting of graupel and cloud water condensation could induce a cooling of $-1.9 \mathrm{~K} \mathrm{~h}^{-1}$ at $4 \mathrm{~km}$ and a heating of $1.0 \mathrm{~K} \mathrm{~h}^{-1}$ at $7.5 \mathrm{~km}$ height, respectively. The small heat source from freezing, reaching $0.3 \mathrm{~K} \mathrm{~h}^{-1}$, should be also noted as compensating the cooling due to cloud evaporation.

\section{Discussion and conclusion}

A squall-line system that passed over Niamey on 11 August 2006 has been analysed by using Doppler radar data collected by the Massachusetts Institute of Technology C-band radar. Even after the system reached the radar (but alas, the data were not saved), regular volume observations were performed at fifteen elevation angles ranging from about $0.5^{\circ}$ to $30^{\circ}$ and within $150 \mathrm{~km}$ around the radar. The squall line propagated westward and its propagation (advection) speed has been objectively determined by considering the radar reflectivity at low levels $(0.3-3 \mathrm{~km})$ and at different observational times. It moved into a relatively sheared and potentially unstable environment when it crossed Niamey. In this study, the kinematic and precipitation structure of the squall line in an early-tomature stage has been detailed, and the prevalent physical processes involved in the momentum transports and in the formation of the observed precipitation have been investigated.

The 3D wind field has been synthesized by applying a multiple-Doppler wind synthesis to a set of three single-radar volume scans obtained every half an hour, when the convective line was at $50-55 \mathrm{~km}$ from the radar. A classical advective procedure has been used to transform these single-radar data into multiple-radar data, which consisted in advecting each measurement point and fixed radar position according to the difference between the observation time and a reference time, under the assumption that the observed features were stationary in the implicit moving frame. Note that the fixed radar position has been advected in order to preserve the viewing angles of the radar beams. The stationarity hypothesis has been verified by comparing the low-level reflectivity pattern in the $1 \mathrm{~h}$ interval, which presented a well-defined and nearly steady convective structure followed by the transition and a portion of the stratiform region.

As a validation of the wind synthesis, the obtained wind field in various horizontal and vertical cross-sections has been found to reveal most common features already described in previous studies. These include the low-level front-to-rear flow opposing a rear-to-front flow originating from convective-scale downdraughts which could progress under the warm inflow to form the well known 
leading gust front favouring the development of new cells, the sloping leading convective updraughts transporting low-level moist air at upper levels, the upper-level detrainment of updraught air into frontward and rearward diverging flows, the convective-scale downdraughts within precipitation cores, and the overall front-to-rear flow at mid-to-upper levels. In the stratiform precipitation region, mesoscale updraught at mid-to-upper levels and mesoscale downdraught at lower levels have also been identified. The upper level frontward and rearward outflows were quite consistent with the forward and trailing anvils observed in a vertical cross-section sampled by the radar.

Momentum transports analysed in the convective region have confirmed the mostly $2 \mathrm{D}$ character of the squall-line internal flow structure, and eddy cross-line transports contributed nearly half the total cross-line transports. The relative importance of the convective vertical motions to the vertical redistribution of mainly cross-line momentum has been further analysed in terms of the respective contribution to acceleration from total advection, vertical flux convergence at mesoscale (area average) and turbulent scale (eddy). Acceleration of frontto-rear flow was concentrated at mid-to-upper levels and turbulent motions accounted for a non-negligible proportion of this vertical redistribution of momentum, by removing momentum from low levels and redistributing it above, yielding a reinforcement of the mid-level frontto-rear flow, and perhaps an increase of the size of the observed system.

In terms of precipitation formation processes, a 1D diagnostic model has been utilized in order to determine the vertical distribution of thermodynamic and microphysical (warm and cold) variables within the convective region and microphysical variables in the transitionstratiform region. The distinct domain-averaged vertical motions and the associated environmental thermodynamic profile (from soundings well ahead of the convective line for the convective region, and near the rear edge of the transition-stratiform domain) were constraining the model based upon microphysical parametrizations established by previous authors and specified boundary conditions. The height distributions of diagnosed mixing ratio of cloud water, cloud ice, rain and graupel-type ice particles were found to be well consistent in shape with those reported in previous studies. In the convective region, these distributions had peak values at $1.5,9.5,1.5$ and $6 \mathrm{~km}$, respectively. Cloud ice, graupel and rain were found to have nearly equal magnitudes while previous studies showed major graupel distribution with peak value three times higher than the peak of the cloud ice mixing ratio. Rain production was mainly associated with accretion of cloud water by rain along with the melting of graupel below the $0^{\circ} \mathrm{C}$ isotherm. Negative fallout of rain tended to reduce this rain production. Graupel was produced through riming and it was augmented by the fallout of graupel from higher levels, compensating the loss due to melting. Finally the corresponding latent cooling rate of $4 \mathrm{~K} \mathrm{~h}^{-1}$ due to melting of graupel could drive the convective-scale downdraught and therefore the associated surface cold pool. In the transition-stratiform region, the various microphysical quantities and their associated processes were found to differ dramatically from those diagnosed in the convective region. The differences were in a proportion quite consistent with the distinct convective and mesoscale vertical motions. The main rain source was from melting of graupel, while sources or sinks of graupel were provided by processes similar to those found in the convective region, but with reduced intensity.

Examination of low-elevation reflectivity pattern has revealed an asymmetry of the north-south oriented squall line with an eastward deflection of the leading convective line at its northern end where a wider rearward extension of the stratiform precipitation occurred. This northern portion of the squall line was associated with a predominance of front-to-rear inflow penetrating deeply inward above $2.5 \mathrm{~km}$ altitude and an absence of lowerlevel rear-to-front flow. The flow organization strongly suggested that small and/or light hydrometeors detrained from the existing convective cells could be advected farther downwind before they fell out. Indeed the upperlevel rearward flow could convey the non-negligible proportion of ice particles farther from the leading deep convection to the trailing stratiform region, therefore favouring the extent of this region.

As a further continuation of the present work, the approach used to inspect the kinematics, thermodynamics and microphysics of a squall line could be extended to the numerous other MCSs observed at Niamey by the MIT Doppler radar during the AMMA SOP. This would provide a complementary view of the main resembling and/or differing internal characteristics of the African monsoonrelated mesoscale convective systems. This study has also discussed the existence of a dusty gust front. Further investigation of the fate of this dusty air could be performed, requiring a detailed analysis of the corresponding low-level flow.

\section{Acknowledgements}

Based on a French initiative, AMMA was built by an international scientific group and is currently funded by a large number of agencies, especially from France, the United Kingdom, the United States of America and Africa. It has been the beneficiary of a major financial contribution from the European Community's Sixth Framework Research Programme. Detailed information on scientific co-ordination and funding is available on the AMMA International web site http://www.ammainternational.org.

Special thanks are due to Earle Williams and Bryan Russell who kindly put the MIT Doppler radar data collected during AMMA at the disposal of the scientific community. The author fully appreciates the numerous improvements to the manuscript suggested by Earle Williams, and also acknowledges two anonymous reviewers for their constructive comments. Sounding data were obtained from the Atmospheric Radiation Measurement 
(ARM) Program sponsored by the US Department of Energy, Office of Science, Office of Biological and Environmental Research, Climate and Environmental Sciences Division.

\section{References}

Avila LA, Pasch RJ. 1995. Atlantic tropical systems of 1993. Mon. Weather Rev. 123: 887-896.

Betts AK, Grover RW, Moncrieff MW. 1976. Structure and motion of tropical squall-lines over Venezuela. Q. J. R. Meteorol. Soc. 102: 395-404.

Biggerstaff MI, Houze RA Jr. 1991. Kinematic and precipitation structure of the 10-11 June 1985 squall line. Mon. Weather Rev. 119: $3034-3065$.

Bluestein HB, Hazen DS. 1989. Doppler-radar analysis of a tropical cyclone over land: Hurricane Alicia (1983) in Oklahoma. Mon Weather Rev. 117: 2594-2611.

Bluestein HB, Hrebenach SD, Chang C-F, Brandes EA. 1994. Synthetic dual-Doppler analysis of mesoscale convective systems. Mon Weather Rev. 122: 2105-2124.

Bou Karam D, Flamant C, Knippertz P, Reitebuch O, Pelon J, Chong M, Dabas A. 2008. Dust emissions over the Sahel associated with the West African monsoon intertropical discontinuity region: A representative case-study. Q. J. R. Meteorol. Soc. 134: 621-634.

Bousquet O, Chong M. 1998. A multiple-Doppler synthesis and continuity adjustment technique (MUSCAT) to recover wind components from Doppler radar measurements. J. Atmos. Oceanic Technol. 15: 343-359.

Braun SA, Houze RA Jr. 1994. The transition zone and secondary maximum of radar reflectivity behind a mid-latitude squall line: Results retrieved from Doppler radar data. J. Atmos. Sci. 51 $2733-2755$.

Braun SA, Houze RA Jr. 1995a. Diagnosis of hydrometeor profiles from area-mean vertical-velocity data. $Q$. J. R. Meteorol. Soc. 121: 23-53.

Braun SA, Houze RA Jr. 1995b. Melting and freezing in a mesoscale convective system. Q. J. R. Meteorol. Soc. 121: 55-77.

Caniaux G, Redelsperger J-L, Lafore J-P. 1994. A numerical study of the stratiform region of a fast-moving squall line. Part $\mathrm{I}$ : General description and water and heat budgets. J. Atmos. Sci. 51 2046-2074.

Caniaux G, Lafore J-P, Redelsperger J-L. 1995. A numerical study of the stratiform region of a fast-moving squall line. Part I I: Relationship between mass, pressure, and momentum fields. $J$. Atmos. Sci. 52: 331-352.

Chen T-C, Wang S-Y, Clark AJ. 2008. North Atlantic hurricanes contributed by African easterly waves north and south of the African easterly jet. J. Climate 21: 6767-6776.

Chong M, Bousquet O. 2001. On the application of MUSCAT to a ground-based dual-Doppler radar system. Meteorol. Atmos. Phys. 78: $133-139$.

Chong M, Cosma S. 2000. A formulation of the continuity equation of MUSCAT for either flat or complex terrain. J. Atmos. Oceanic Technol. 17: 1556-1564.

Chong M, Hauser D. 1989. A tropical squall line observed during the COPT 81 experiment in West Africa. Part II: Water budget. Mon Weather Rev. 117: 728-744.

Chong M, Testud J, Roux F. 1983. Three-dimensional wind field analysis from dual-Doppler radar data. Part II: Minimizing the error due to temporal evolution. J. Appl. Meteorol. 22: 1216-1226.

Chong M, Amayenc P, Scialom G, Testud J. 1987. A tropical squall line observed during the COPT 81 experiment in West Africa. Par I: Kinematic structure inferred from dual-Doppler radar data. Mon. Weather Rev. 115: 670-694.

Chong, M, Georgis J-F, Bousquet O, Brodzik SR, Burghart C, Cosma S, Germann U, Gouget V, Houze RA Jr, James CN, Prieur S, Rotunno R, Roux F, Vivekanandan J, Zeng Z-X. 2000. Real-time wind synthesis from Doppler radar observations during the Mesoscale Alpine Programme. Bull. Am. Meteorol. Soc. 81: 2953-2962.

Crumeyrolle S, Gomes L, Tulet P, Matsuki A, Schwarzenboeck A, Crahan K. 2008. Increase of the aerosol hygroscopicity by aqueous mixing in a mesoscale convective system: A case study from the AMMA campaign. Atmos. Chem. Phys. Discuss. 8: 10057-10103.

Fortune M. 1980. Properties of African squall lines inferred from timelapse satellite imagery. Mon. Weather Rev. 108: 153-168.
Fovell RG, Ogura Y. 1988. Numerical simulation of a mid-latitude squall line in two dimensions. J. Atmos. Sci. 45: 3846-3879.

Futyan JM, Del Genio AD. 2007. Deep convective system evolution over Africa and the tropical Atlantic. J. Climate 20: 5041-5060.

Gal-Chen T. 1982. Errors in fixed and moving frames of reference: Applications for conventional and Doppler radar analysis. J. Atmos. Sci. 39: 2279-2300.

Gamache JF, Houze RA Jr. 1982. Mesoscale air motions associated with a tropical squall line. Mon. Weather Rev. 110: 118-135.

Georgis JF, Roux F, Hildebrand PH. 2000. Observation of precipitation systems over complex orography with meteorological Doppler radars: A feasibility study. Meteorol. Atmos. Phys. 72: 185-202.

Hamilton RA, Archbold JW, Douglas CKM. 1945. Meteorology of Nigeria and adjacent territory. Q. J. R. Meteorol. Soc. 71: 231-262.

Hauser D, Roux F, Amayenc P. 1988. Comparison of two methods for the retrieval of thermodynamic and microphysical variables from Doppler radar measurements: Application to the case of a tropical squall line. J. Atmos. Sci. 45: 1285-1303.

Hopsch SB, Thorncroft CD, Hodges K, Aiyyer A. 2007. West African storm tracks and their relationship to Atlantic tropical cyclones. J. Climate 20: 2468-2483.

Houze RA Jr. 1977. Structure and dynamics of a tropical squall-line system. Mon. Weather Rev. 105: 1540-1567.

Houze RA Jr. 2004. Mesoscale convective systems. Rev. Geophys. 42: RG4003, DOI:10.1029/2004RG000150.

Houze RA Jr, Betts AK. 1981. Convection in GATE. Rev. Geophys. 19: $541-576$.

Houze RA Jr, Rappaport EN. 1984. Air motion and precipitation structure of an early summer squall line over eastern tropical Atlantic. J. Atmos. Sci. 41: 553-574.

Houze RA Jr, Biggerstaff MI, Rutledge SA, Smull BF. 1989. Interpretation of Doppler weather radar displays in mid-latitude mesoscale convective systems. Bull. Am. Meteorol. Soc. 70: 608-619.

Houze RA Jr, Smull BF, Dodge P. 1990. Mesoscale organization of springtime rainstorms in Oklahoma. Mon. Weather Rev. 118: 613-654.

Huffman GJ, Adler RF, Bolvin DT, Gu G, Nelkin EJ, Bowman KP, Hong Y, Stocker EF, Wolff DB. 2007. The TRMM Multisatellite Precipitation Analysis (TMPA): Quasi-global, multiyear, combinedsensor precipitation estimates at fine scales. J. Hydrometeorol. 8: $38-55$.

Kessler E. 1969. On the distribution and continuity of water substance in atmospheric circulation. Meteorol. Monogr. 32: 84 pp.

Klimowski BA, Marwitz JD. 1992. The synthetic dual-Doppler analysis technique. J. Atmos. Oceanic Technol. 9: 728-745.

Lafore J-P, Moncrieff MW. 1989. A numerical investigation of the organization and interaction of the convective and stratiform regions of tropical squall lines. J. Atmos. Sci. 46: 521-544.

Lafore J-P, Chapelet P, Mumba Z, Chapelon N, Dufresne M, Agbabu R, Abdoul-Aziz A, Hamidou H, Asencio N, Couvreux F, Nuret M, Garba A. 2008. 'Forecaster's guide for West African Synthetic Analysis/Forecast.' Report of AMMA Project No. 004089, 11 pp. Available online at https://www.ammaeu.org/sections/work_packages/process-studies/wp2_1/deliverables/.

Landsea CW, Bell GD, Gray WM, Goldenberg SB. 1998. The extremely active 1995 Atlantic hurricane season: Environmental conditions and verification of seasonal forecasts. Mon. Weather Rev. 126: $1174-1193$

Leary CA, Houze RA Jr. 1979. The structure and evolution of convection in a tropical cloud cluster. J. Atmos. Sci. 36: 437-457.

Lin Y-L, Farley RD, Orvill HD. 1983. Bulk parameterization of the snow field in a cloud model. J. Appl. Meteorol. 22: 1065-1092.

Locatelli JD, Hobbs PV. 1974. Fall speeds and masses of solid precipitation particles. J. Geophys. Res. 79: 2185-2197.

Lothon M, Saïd F, Lohou F, Campistron B. 2008. Observation of the diurnal cycle in the low troposphere of West Africa. Mon. Weather Rev. 136: 3477-3500.

Marécal V, Hauser D, Roux F. 1993. The 12/13 January 1988 narrow cold-frontal rainband observed during MFDP/FRONTS 87. Part II: Microphysics. J. Atmos. Sci. 50: 975-998.

Mathon V, Diedhiou A, Laurent H. 2002a. Relationship between easterly waves and mesoscale convective systems over the Sahel. Geophys. Res. Lett. 29: 1216, DOI:10.1029/2001GL014371.

Mathon V, Laurent H, Lebel T. 2002b. Mesoscale convective system rainfall in the Sahel. J. Appl. Meteorol. 41: 1081-1092. 
Moncrieff MW. 1992. Organized convective systems: Archetypal dynamical models, mass and momentum flux theory, and parametrization. Q. J. R. Meteorol. Soc. 118: 819-850.

Payne SW, McGarry MM. 1977. The relationship of satellite inferred convective activity to easterly waves over West Africa and the adjacent ocean during Phase III of GATE. Mon. Weather Rev. 105: 413-420.

Redelsperger J-L, Thorncroft CD, Diedhiou A, Lebel T, Parker DJ, Polcher J. 2006. African Monsoon Multidisciplinary Analysis. An international research project and field campaign. Bull. Am. Meteorol. Soc. 87: 1739-1746.

Reed RJ, Norquist DC, Recker EE. 1977. The structure and properties of African wave disturbances as observed during Phase III of GATE. Mon. Weather Rev. 105: 317-333.

Risi C, Bony S, Vimeux F, Chong M, Descroix L. 2009. Evolution of the water stable isotopic composition of the rain sampled along Sahelian squall lines. Q. J. R. Meteorol. Soc. 136(s1): 228-243.

Roux F, Ju S. 1990. Single-Doppler observations of a West African squall line on 27-28 May 1981 during COPT 81: Kinematics, thermodynamics and water budget. Mon. Weather Rev. 118: $1826-1854$.

Rowell DP, Milford JR. 1993. On the generation of African squall lines. J. Climate 6: 1181-1193.

Rutledge SA, Hobbs PV. 1983. The mesoscale and microscale structure and organization of clouds and precipitation in mid-latitude cyclones. VIII: A model for the 'seeder-feeder' process in warm-frontal rainbands. J. Atmos. Sci. 40: 1185-1206.

Rutledge SA, Hobbs PV. 1984. The mesoscale and microscale structure and organization of clouds and precipitation in mid-latitude cyclones. XII: A diagnostic modeling study of precipitation development in narrow cold-frontal rainbands. J. Atmos. Sci. 41: 2949-2972.
Schumacher C, Houze RA Jr. 2006. Stratiform precipitation production over sub-Saharan Africa and the tropical east Atlantic as observed by TRMM. Q. J. R. Meteorol. Soc. 132: 2235-2255.

Skamarock WC, Weisman ML, Klemp JB. 1994. Three-dimensional evolution of simulated long-lived squall lines. J. Atmos. Sci. 51: $2563-2584$.

Smull BF, Houze RA Jr. 1987. Rear inflow in squall lines with trailing stratiform precipitation. Mon. Weather Rev. 115: 2869-2889.

Sultan B, Janicot S, Drobinski P. 2007. Characterization of the diurna cycle of the West African monsoon around the monsoon onset. J. Climate 20: 4014-4032.

Thorncroft CD, Hodges K. 2001. African easterly wave variability and its relationship to Atlantic tropical cyclone activity. J. Climate 14: 1166-1179.

Williams E, Renno N. 1993. An analysis of the conditional instability of the tropical atmosphere. Mon. Weather Rev. 121: 21-36.

Yang M-J, Houze RA Jr. 1996. Momentum budget of a squall line with trailing stratiform precipitation: Calculations with a high-resolution numerical model. J. Atmos. Sci. 53: 3629-3652.

Young D. 1954. Iterative methods for solving partial difference equations of elliptic type. Trans. Am. Math. Soc. 76: 92-111.

Zhang J, Wang S. 2006. An automated 2D multipass Doppler radar velocity dealiasing scheme. J. Atmos. Oceanic Technol. 23: $1239-1248$.

Zipser EJ. 1969. The role of organized unsaturated convective downdrafts in the structure and rapid decay of an equatorial disturbance. J. Appl. Meteorol. 8: 799-814.

Zipser EJ. 1977. Mesoscale and convective-scale downdrafts as distinct components of squall-line structure. Mon. Weather Rev. 105: $1568-1589$. 